\title{
حماية البيئة المائية
}

\author{
دكتور \\ أحمد محمد أحمد الزيز لونئ \\ رئيس قسم الحقوق - كلية الآداب والعلوم التطبيقية \\ جامعة ظفار. سلطنة عمان قسم القانون الخاص \\ كلية القانون - جامعة شندي_السودان
}





\section{|lll|}

هذه الدراسة تهدف لدر اسة موضوع حماية البيئة المائية في قانون حماية البيئة

$$
\text { خلصت الار اسة إلي : }
$$

إن الماء يشمل المياه السطحية أو الجوفية، سوء كانت عذبة أو مالحة أو

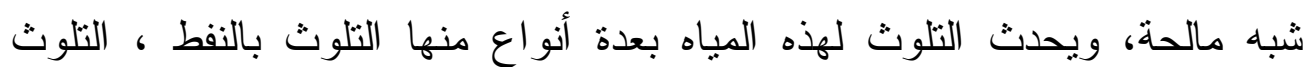
الحراري، و التلوث الكيمائي، كما أن مصادر التلوث المائي متعددة. تعرض البحث للوسائل الإدارية لحماية البيئة العمانية إذ أن الوسائل القانونية

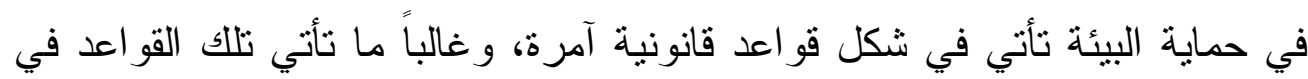
صيغة النهي و الأمر و الإلز ام و الحظر، وهنالك العديد من الوسائل القانونية التي يكون الغرض منها حماية البيئة من التلوث. تتاول البحث أركان وأنواع جرائم التلوث المائي حيث أوضح بأن هنالك عدد

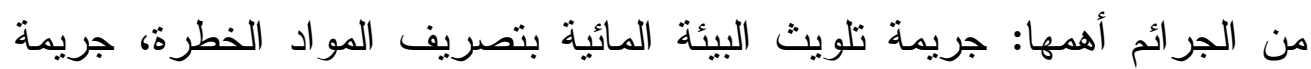
تلويث البيئة المائية بتصريف الزيت، جريمة التخلص من المخلفات النووية، كما أن هنالك تجريم وقائي الهدف منه الحد من تلوث البيئة المائية .

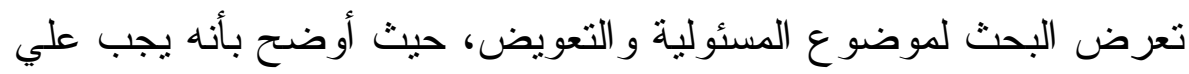
من يتسبب في تلوث المياه دفع التكاليف اللازمة لإرجاع البيئة المائية للحالة التي كانت عليها قبل حدوث التلوث . أخير اً تتاول البحث موضوع المحاكم المختصة، حيث أوضح بأن المحاكم

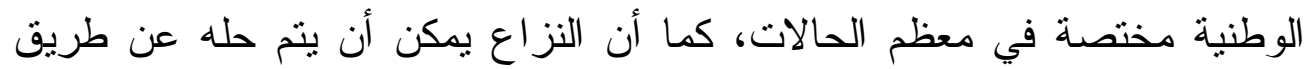
التحكيم و الصلح، كما أن هناللك اختصاص ينعقد لمحكمة العدل الدولية . وقد توصل البحث إلى عدة نتائج واختتم البحث بعدد من التوصيات التي قد تعين

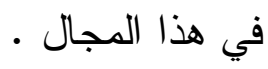




\section{مقدمهة}

إن موضوع البحث من الموضوعات التي لها أهمية عظمي، إذ أن البيئة هي

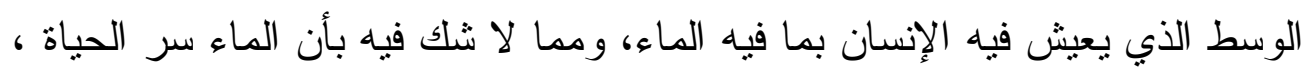

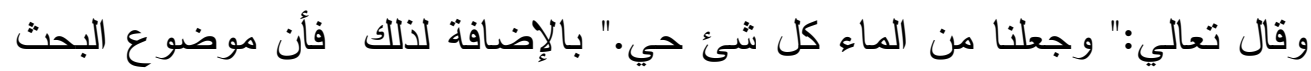

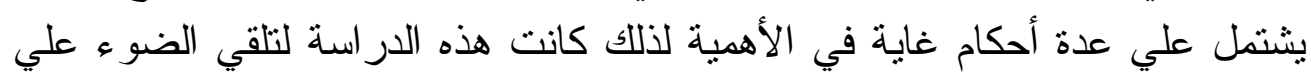
ن تلك الأحكام مما لا ريب فيه بأن الماء العذب الصالح للثرب و الاستعمالات البشرية قليل جداً،

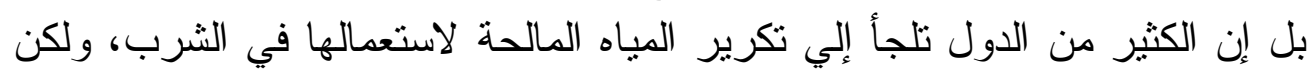

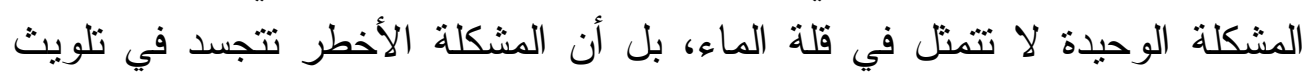
المياه و الذي يتضرر من جر اء ذلك الفعل الإنسان وكذلك الإحياء المائية .

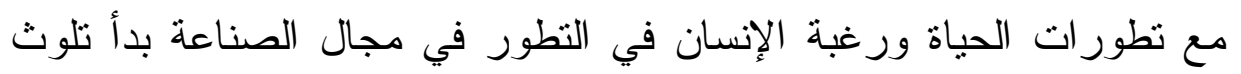

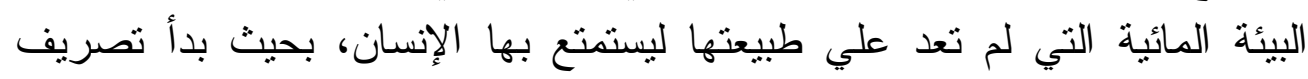

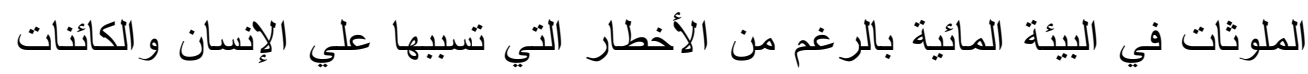

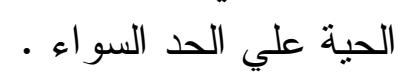

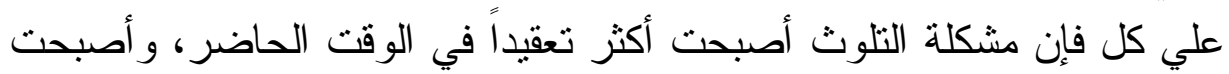

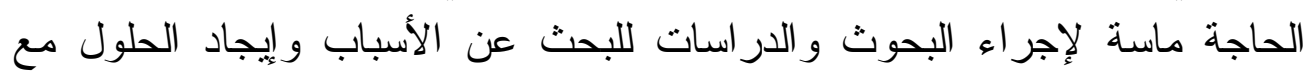

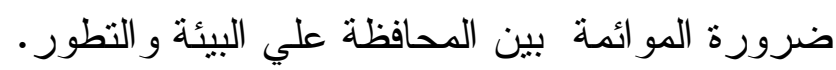

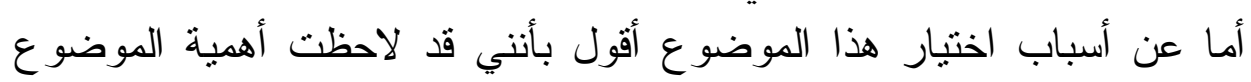

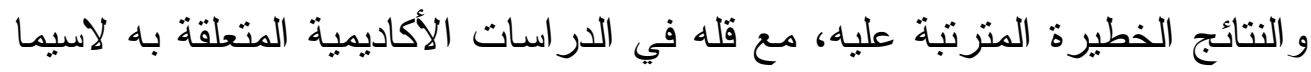

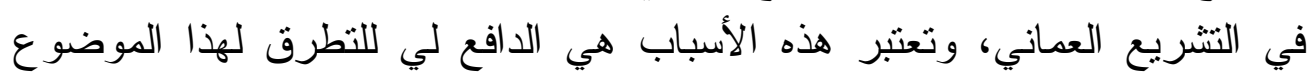

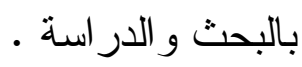

وتحقيقاً لأهداف البحث ولثة ولي هدى من مشكلته وفروضه فقد نم تقسيمه إلى خمسة

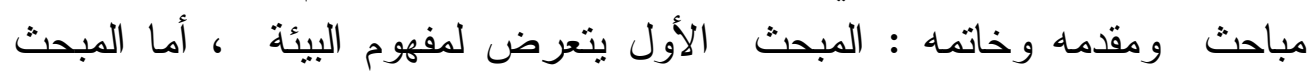

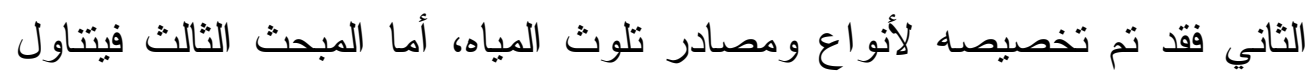

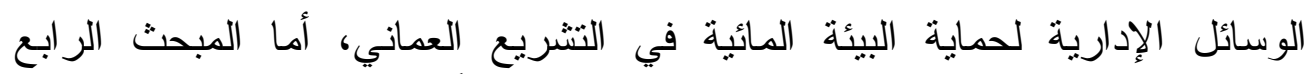

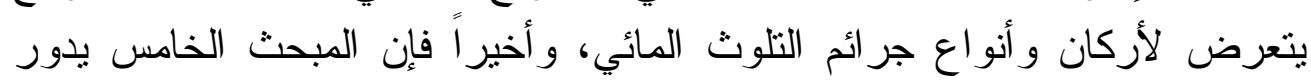
حول المسئولية و التعويض و الركان وانو جرم المختصة . 


\section{المبمث الأول \\ مغهوم البينة}

أولاً - تعريف البيئة في اللغة :

إن كلمة بيئة كلمة عربية الأصل لها جذور في القرآن الكريم و السنة النبوية

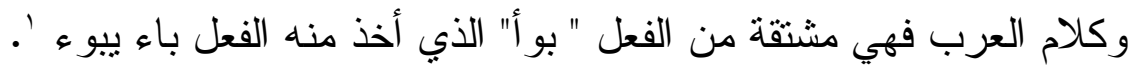

جاء في تعريفها :" المباءة هو المنزل ، ومنبوء الولا من الرحم ، و البيئة تعني بوني

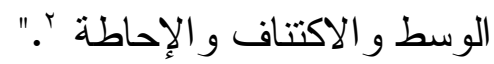

وجاء في تعريفها أيضًاً :" البيئة المنزل وما حول المنزل من أماكن ومساكن ، فبيئة

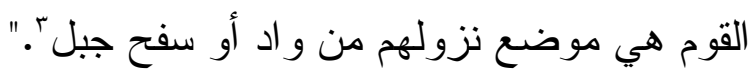

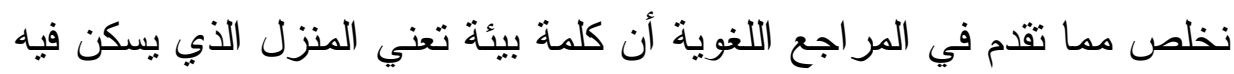

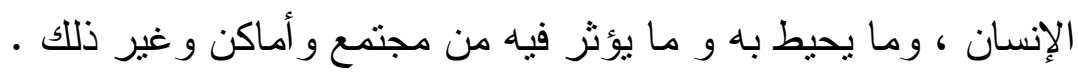
ثانياً - معني البيئة في القرآن آن الكريم :

وردت كلية البيئة بمعني المنزل و المسكن في العديد من الآيات : ا-قال تعالي :" ولقد بوأنا بني إسر ائيل موبأ صدق ورزقناهم من الطيبات فما

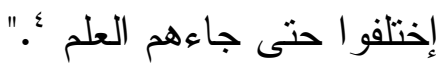

r- وقال تعالي :" وكذلك مكنا ليوسف في الأرض يتبو أ منها حيث يشاء نصيب

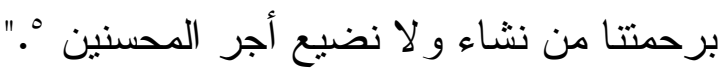

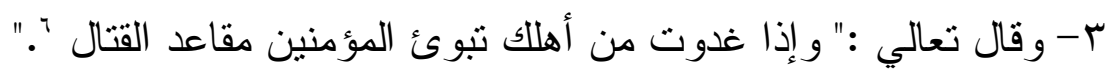

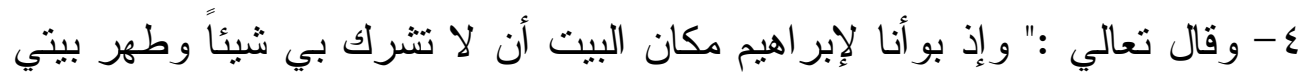

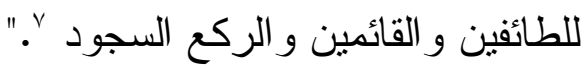

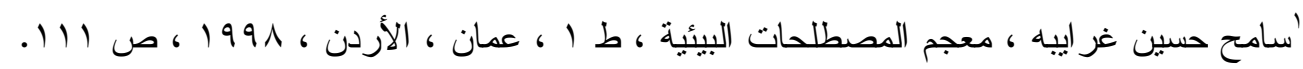

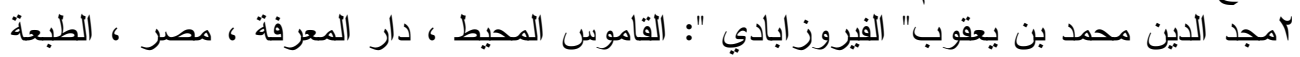

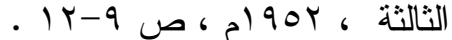

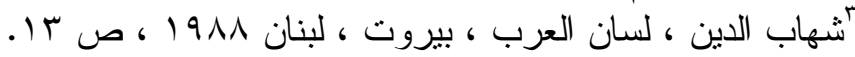

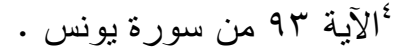

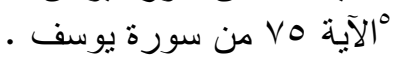

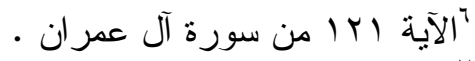

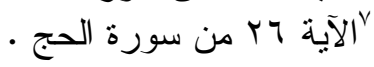


ه- وقال تعالي :" و الذين هاجرو ا في الله من بعد ما ظلمو النبوئنهم في الدنيا حسنة

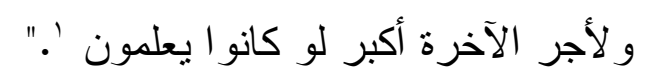

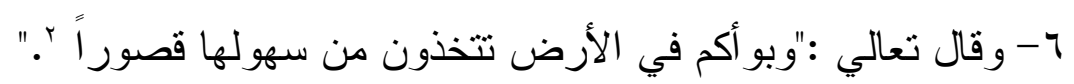

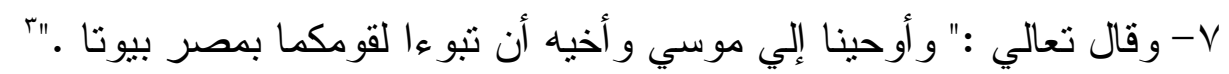

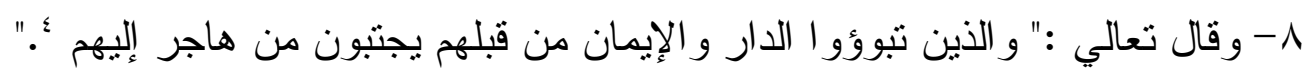
و- وقال تعالي :" وقالو ا الحمد لله الذي صدقنا و عده و أورثتا الأرض نتبو أ من الجنة

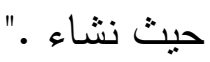

• ا - وقال تعالي :" و الذين آمنو ا و عملو الصالحات لنبوئنهم من الجنة غرفا هـ" ثالثاً - المعني الاصطلاحي للبيئة: تتوع التعريف بالبيئة وتعدد ولكن لا بد من الإشارة إلي أهم نلاك التعريفات : البيئة مجمو عة العو امل البيولوجية و الكيماوية و الطبيعية و الجغر افية و المناخية

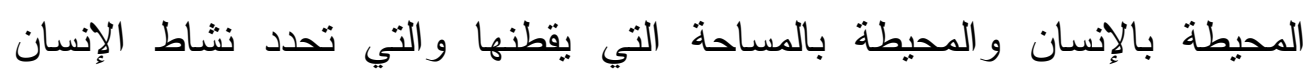

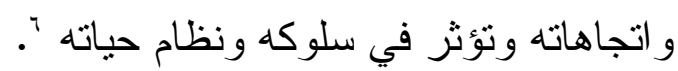
وجاء أيضاً في تعريفها :" هي المجال الذي تحدث فيه الإثارة و التفاعل لكل وحدة حية وهي كل ما يحيط بالإنسان من طبيعة ومجتمعات بشرية ونظم اجتماعية

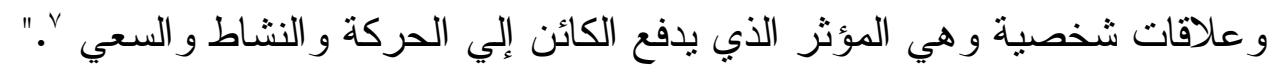
وقد ورد في تعريفها :" الإطار الذي بعيش فيه الإنسان ويحصل منه عله مقومات حياته من غذاء وكساء ودو اء ومأوي ويمارس فيه علاقاته دع أقر انه من

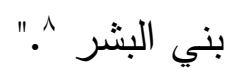

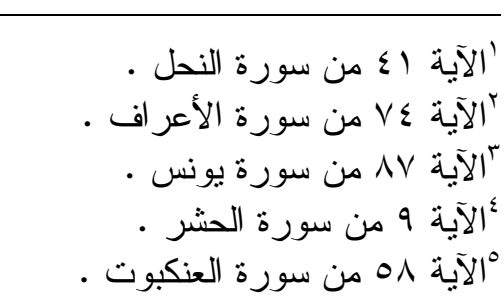

Tد. حمدي عطية مصطفي عامر ، حماية البيئة في النظام القانوني الوضعي والإنية ، الإسلامي ، دار

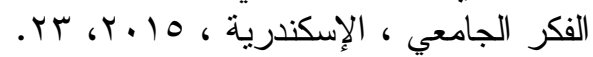

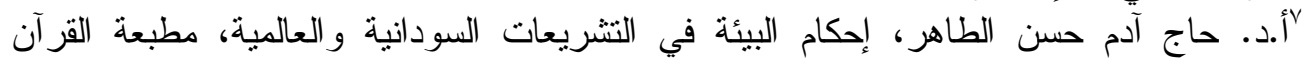

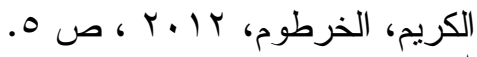
^محد عبدالقادر الفقي، البيئة مشاكلها وقضاياها وحمايتها من التلوث، القاهرة، سو 19 م، ص 


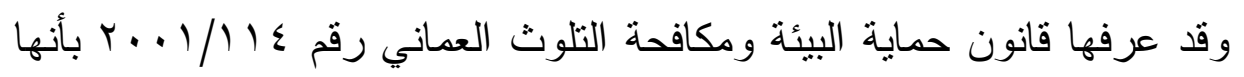

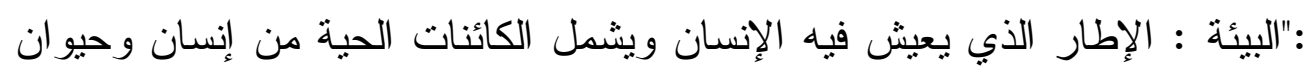

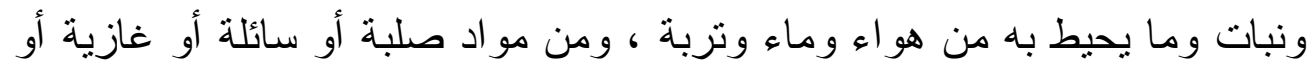

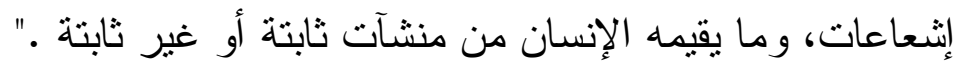
من خلال تلك التعريفات يمكن النظر إلي البيئة بأنها كل ما مانئة يحيط بالإنسان

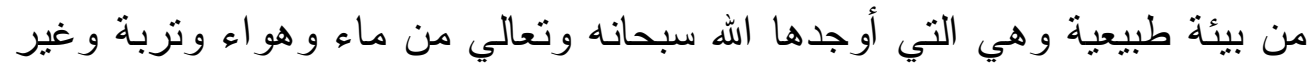
ذللك وبيئة قام بصنعها الإنسان مثل المباني و المصانع و غير ذللك مما يقوم بصنعه الإنسان

\section{المبمث الثاني \\ أنواع ومصادر تلوث الياه}

الماء يشمل المياه السطحية أو الجوفية، سوء كانت عذبة أو مالحة أو شبه مالحة' . ماء يعتبر الماء في الكرة الأرضية كثير بالمقارنة لحجم اليابسة، إذ تبلغ مساحة

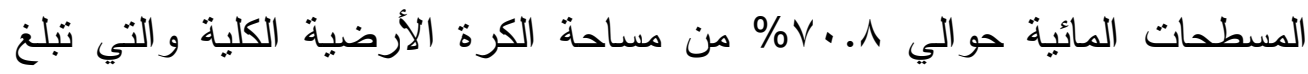

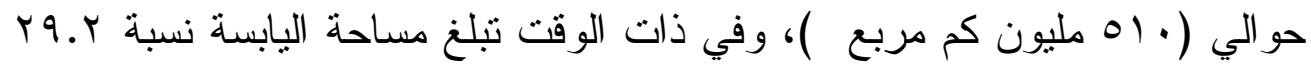

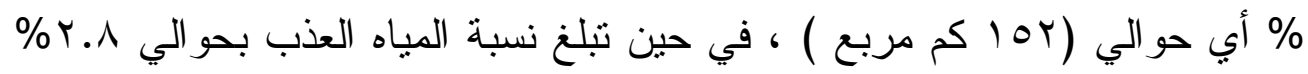

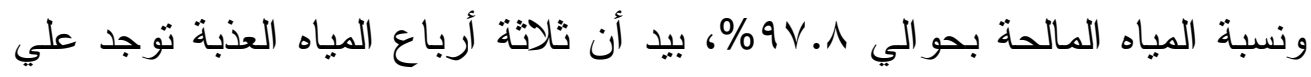

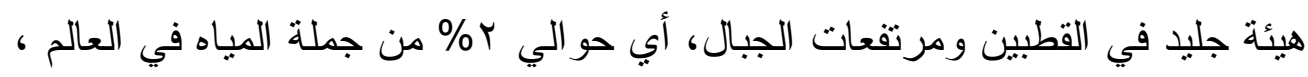

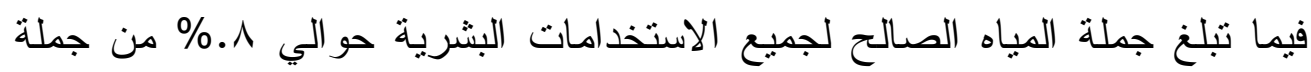

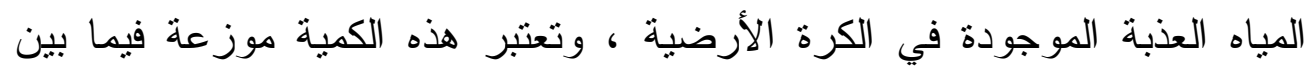

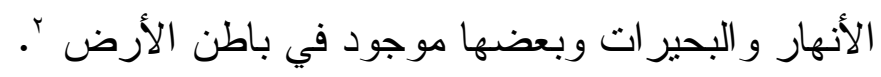

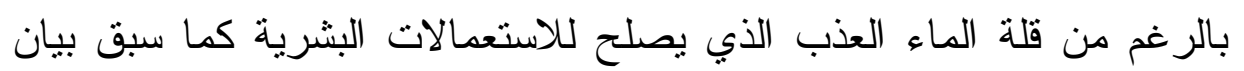

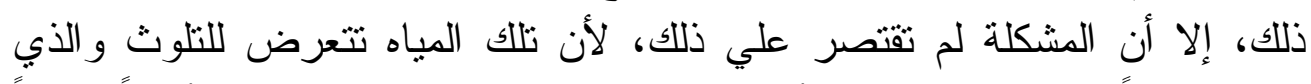

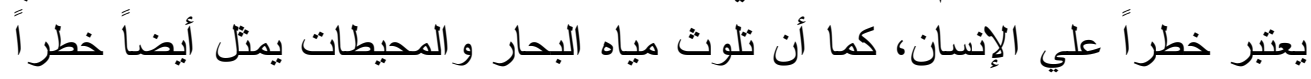

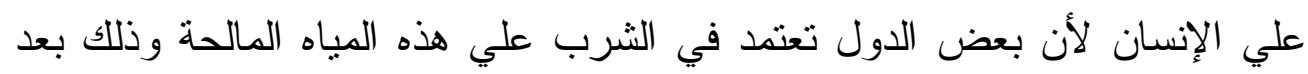

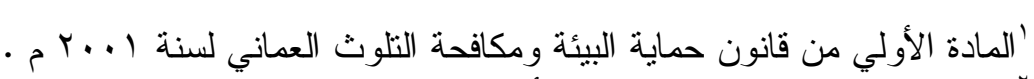

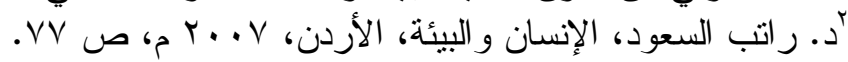


تتقيتها، أضف إلي ذلك إن التلوث أيضاً ذا خطورة علي الكائنات الحية و التي تعتبر

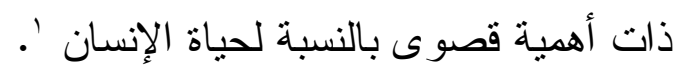

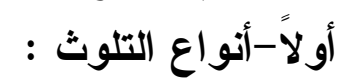

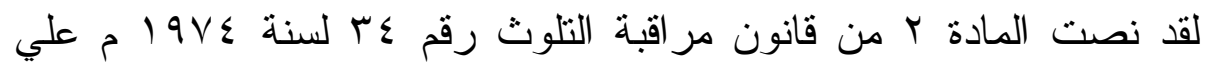

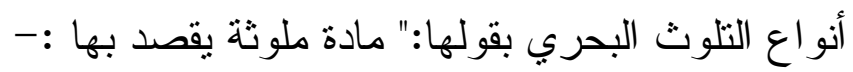

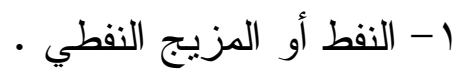

ب-أية مادة ذات طبيعة خطرة أو ضارة مثن مياه المصارف أو النفايات أو

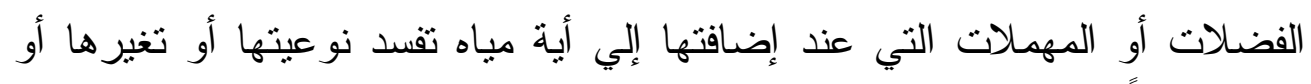
تشكل جزءاً من عملية إفساد نوعية هذه المياه أو تغيير ها إلي حد الخطر بالنسبة إلي استعمالها من قبل الإنسان أو أية حيوانات أو أسماك أو نباتات مفيدة للإنسان، شريطة ألا تعتبر مثل هذه التصريفات، التي لا تصدر عن مصادر صناعية أو تجارية، مو اد ملوثة ما لم يصدر الوزير أنظمة بموجب القانون تتص علي خلاف ذلك ب-أية مو اد محتوية علي مادة ما بكمية أو تزكيز معين أو معالجة مصنعة أو مغيرة من حالتها الطبيعية، إما بالحر ارة و إما بأية وسيلة أخري، بحيث إذا أضيفت إلي أي مياه أدت إلي إفساد نوعية تلك المياه أو تغييرها أو شكلت جزءاً من عملية أفساد نو عية تلك المياه أو تغيير ها إلي الحد الخطر بالنسبة إلي استعمالها من قبل الإنسان

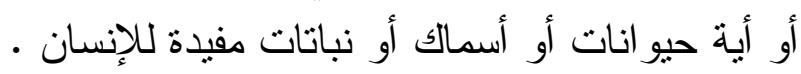
ع-أية مادة قد يصنفها الوزير كمادة ملوثنة وفقاً لآية أنظمة صادرة بموجبان هذا القانون. أ-التلوث الحراري : بعتبر هذا النوع صورة من صور التلوث، حيث ثقوم محطات

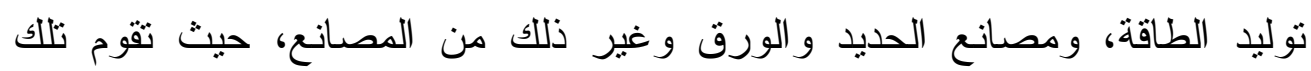
المحطات باستعمال مباه الأنهار و البحير ات في عمليات التبريد، وصرف، وف ولئ المياه الساخنة إلي مياه الأنهار، وتسبب تلك المياه الساخنة في موت الكثير من الأحياء المائية باجية

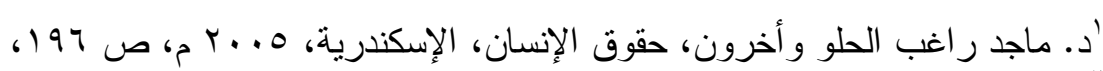

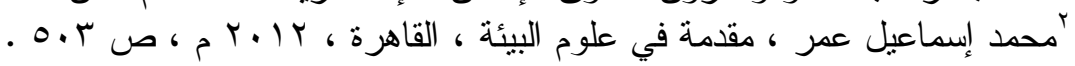




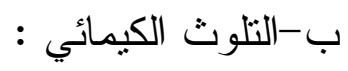

نتيجة لإلقاء بعض المو اد الكيمائية في المسطحات المائية منل الزئبق أو الرصاص

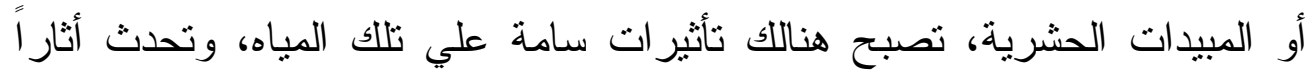
ضارة علي كل الأحياء المائية، ومن الصعب هصب حصر تلاك المواد الكيمائية التي يقدر

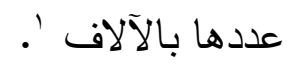

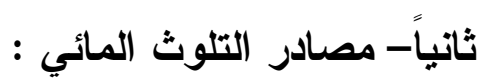
ا -مصادر بشرية وحيو انية :

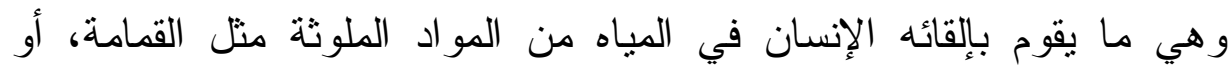

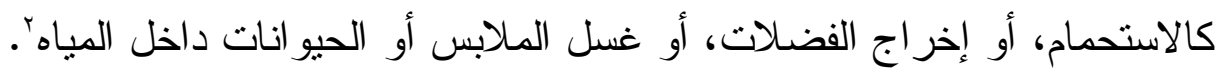

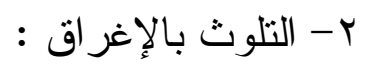

المقصود بذلك التخلص المتعمد بحر اً لنفايات أو أية مواد أخري من منشآت

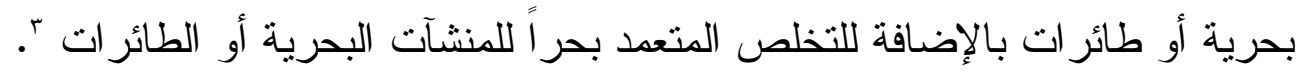

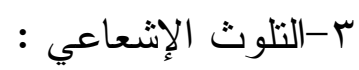
يحدث ذلك النوع من التلوث نتيجة لانتشار المو اد المشعة جراء التجارب التي لأي

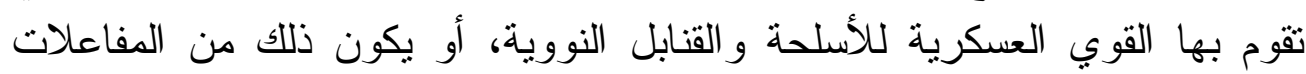

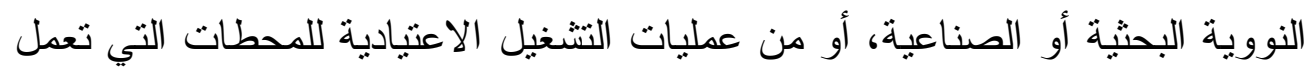

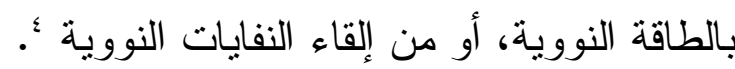

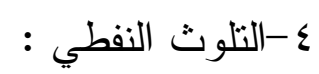
هنالك العديد من الأسباب التي تؤدي إلي تلوث المياه بالنفط، فقد يحدث ذلك الكي

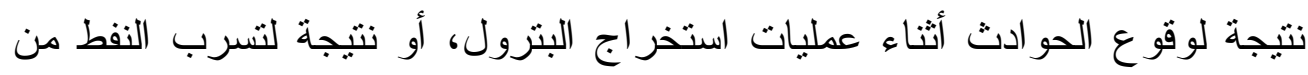
بعض آبار البنزول التي تقع بالقرب من المياه، أو بسبب تلف بعض أنابيب البترول

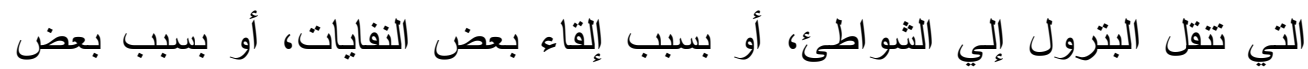

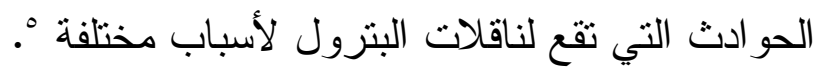

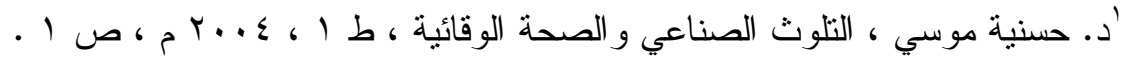

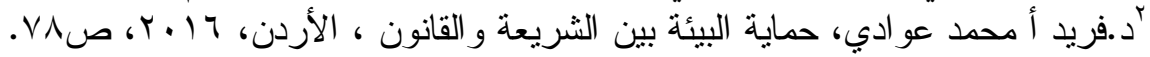

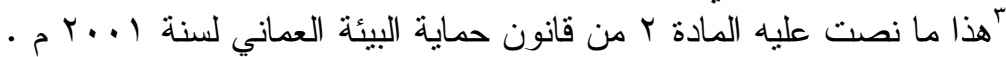

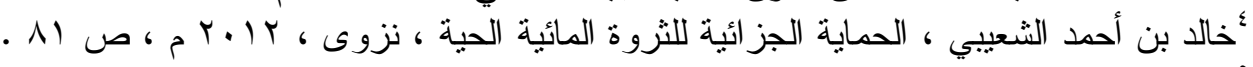

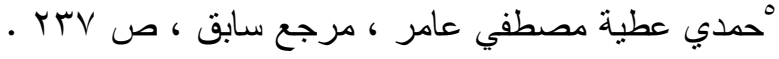


هذا وقد وقعت العديد من الحوادث التي أدت إلي التلوث المائي ونشأ عن ذلك

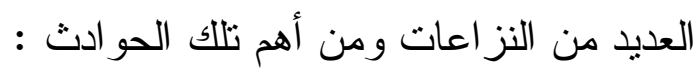

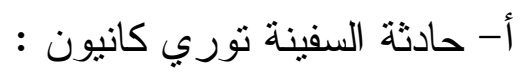

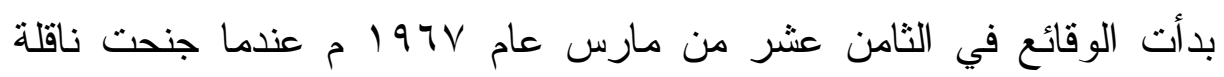

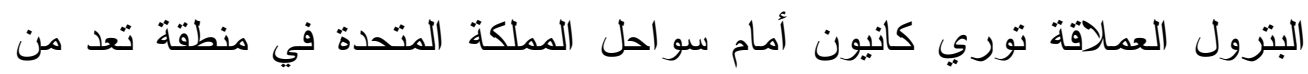

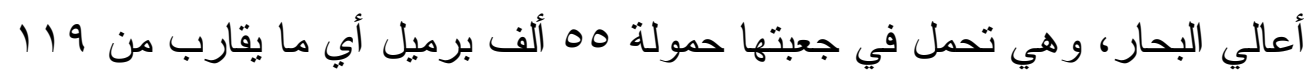

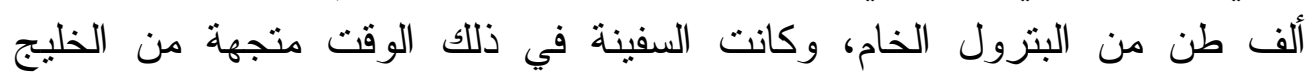

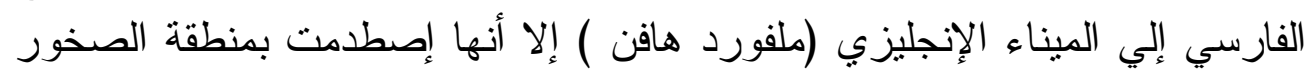

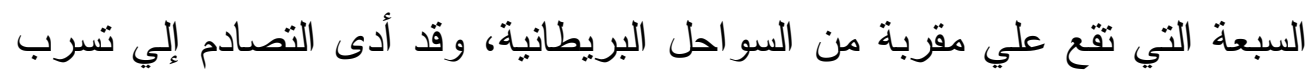

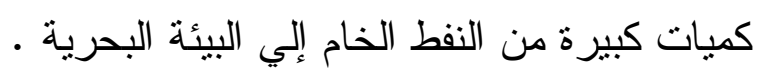
في الحادي و العشرين من مارس عام 197 مات م وبينما كانت عمليات الإنقاذ جارية للناقلة علي قدم وساق حدث انفجار في غرفة الآلات و أحدث هذا هذا الانفجار

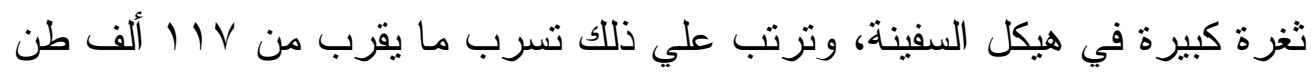

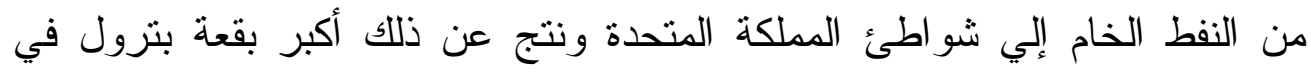

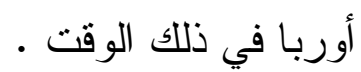
وقد بذلت محاو لات عديدة لتعويم السفينة وتذويب بقع الزيت علي سطح الماء

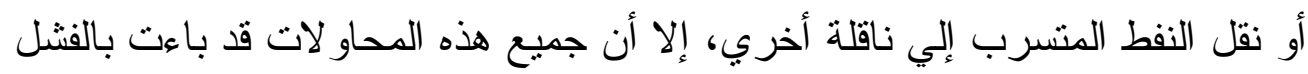

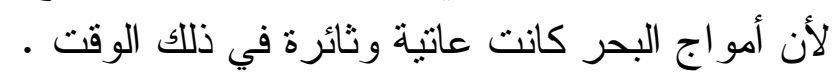

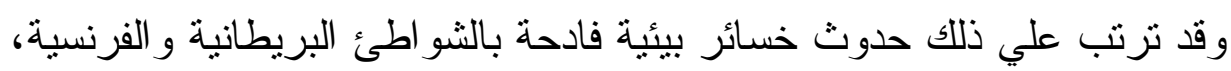

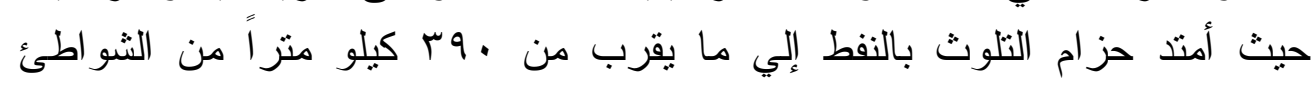
البريطانية و الفرنسية مما أضطر حكومة المملكة المتحدة إلي التذخل لتدمير السفينة توري كانيون ورسم خط النهاية لهذه الكارثة البحرية المدوية، وقد حدث ذلكة فلك بالفعل

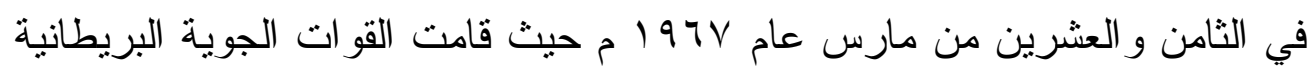

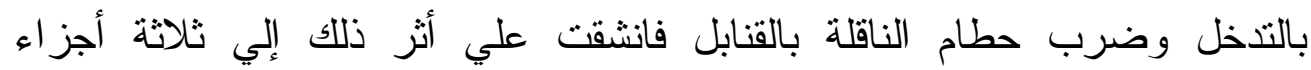
متناثرة، وكان الهدف من التنخل حرق ما تنقي من نفط في صهاريج الناقلة العملاقة لمنعه من التمدد والانتشار ، وكذا التخلص من الزيوت النفطية المتخلفة عن هذه

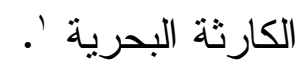

'سامح عبدالقوي، التخخلات الدولية لحماية البيئة، مركز الدراسات العربية، الجيزة، مصر ،

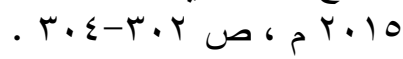


ب- غرق ناقلة النفط برستيج:

من الأمنلة علي الكوارث البيئية المائية علي وقعت وكانت لها نتائج كارثية

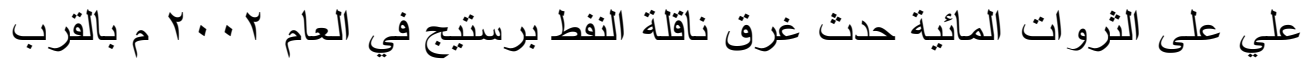
من السواحل الأسبانية و الذي أحدث تلوث نفطي شديد لثو الثئ أسبانيا و البرتغال

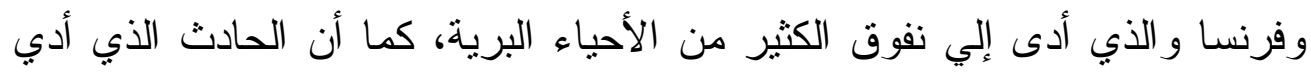

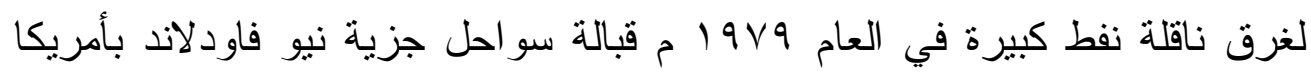

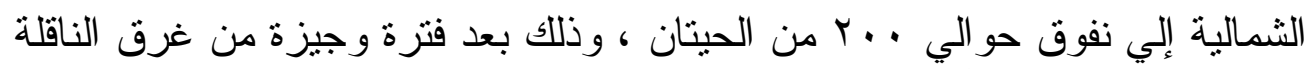

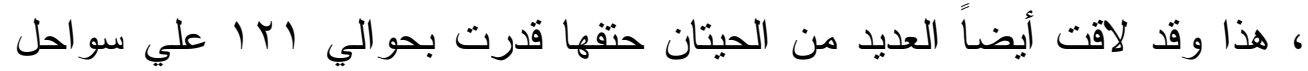

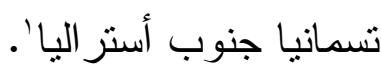

ج - غرق ناقلة البترول أكسون فالديز :

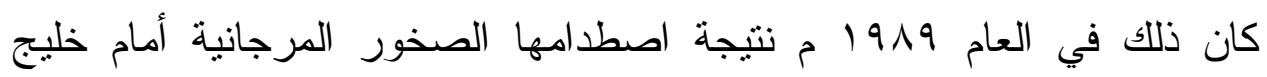
برنس ويليام بألاسكا، وكان نتيجة غرقها هو محاولة السفينة تفادي الارتطام بأحد

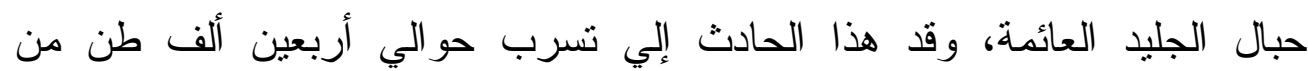
البترول، وقد انتشرت بقعة البترول لمسافة تبلغ ألف ميل، وبعد مرور أسبوعين

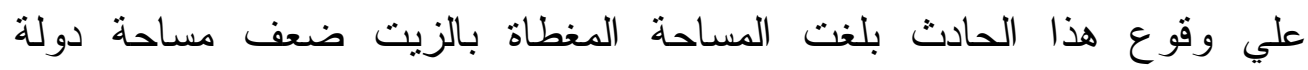
لكسمبورج مما أدي إلي تلوث تلاك الثواطئ وحدوث أضر ار كبيرة للأحياء المائية

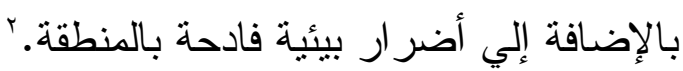

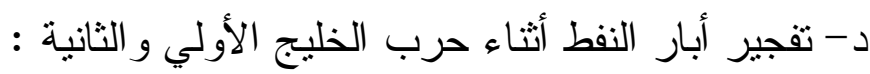

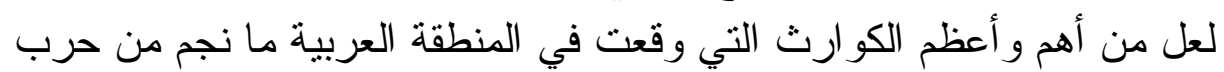

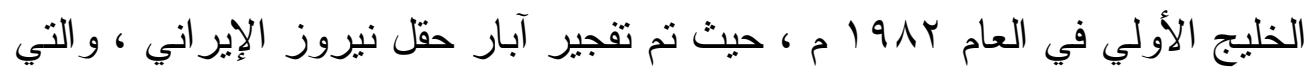

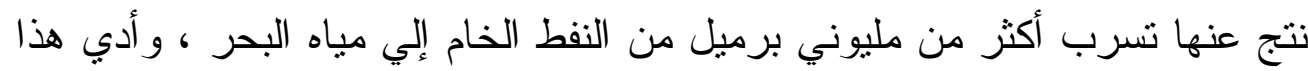

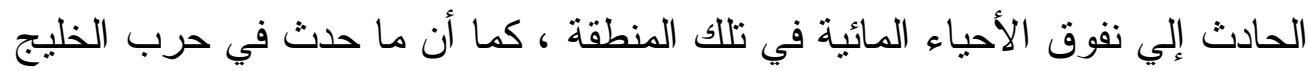

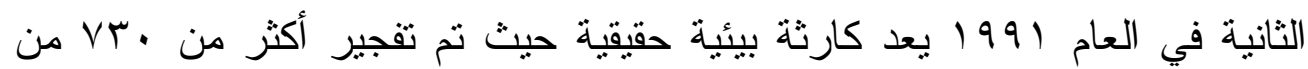
حقول النفط الكويتية ، وتسبب ذللك في دمار البيئة بشكل كلي، أدي إلي موت الأحياء

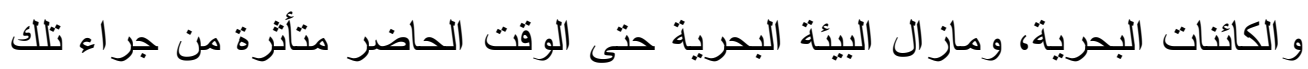
الحادثة ؟ّ

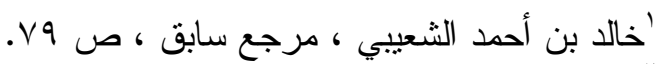

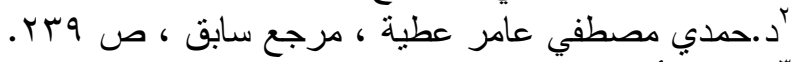

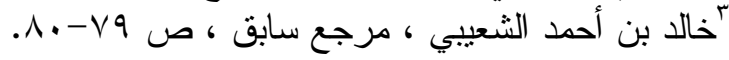




\section{المبمث الثالث}

\section{الوسائل الإدارية لمماية البيئة المانية في التشريع العماني في التئي}

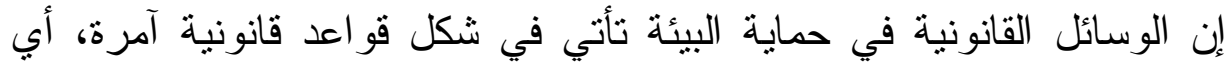

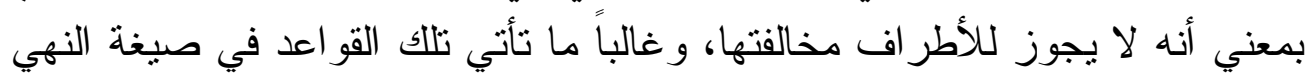

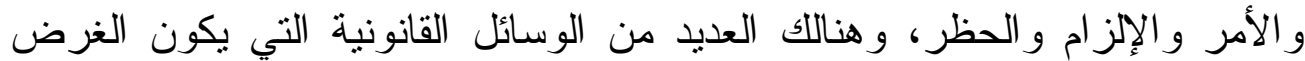

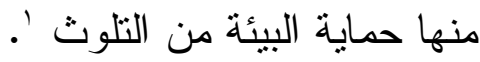

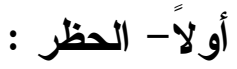

1- حظر تصريف المو اد الملوثة في المياه :

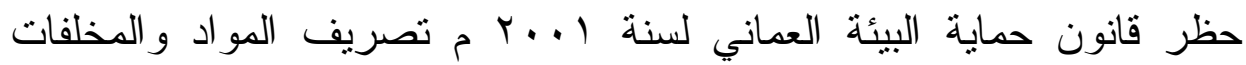

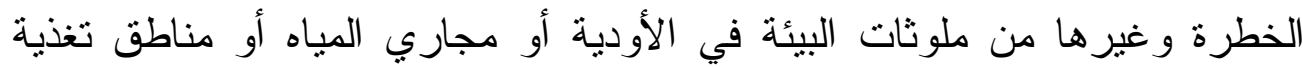

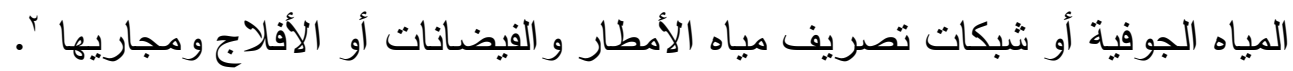

$$
\text { r-حظر تصريف الزيت في المياه : }
$$

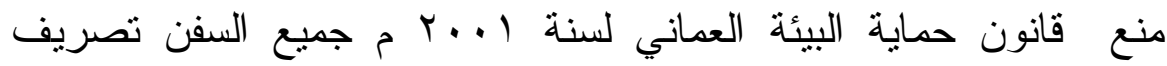
الزيت أو المزيج الزيتي أو أي ملوثات بيئية في المياه الداخلية أو في المياه الإقليمية ؟.

r-حظر تصريف المخلفات من عمليات استكثاف و استغلال الموارد الطبيعية :

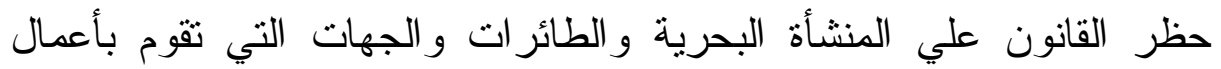

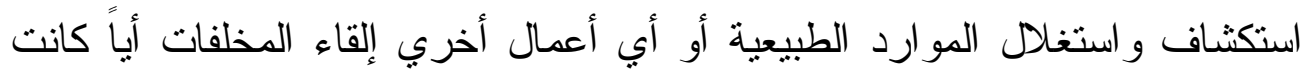

$$
\begin{aligned}
& \text { في المياه الإقليمية ؛. } \\
& \text { ثانياً الإلز ام : }
\end{aligned}
$$

قد يقوم القانون بإلز ام الأفر اد بالقيام ببعض الأعمال المعينة وذلك لضمان حماية

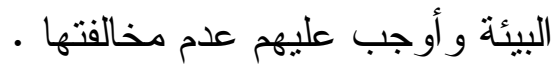
1-الإلز ام بالحصول علي تصريح لتصريف مياه الصرف الصحي :

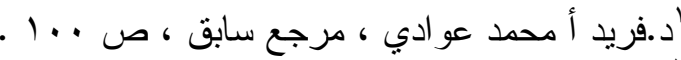

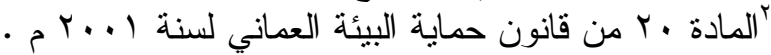

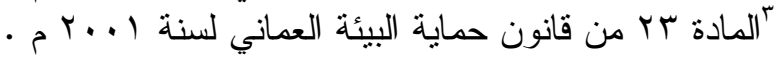

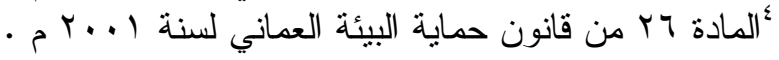


أوجب القانون عدم تصريف مياه الصرف غير المعالجة في الأودية أو مجاري

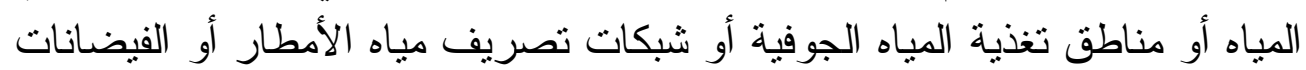
أو الأفلاج أو مجاريها من أونذية المياه

بيد أن القانون في ذات الوقت قام بالإلز ام بعدم تصريف مياه الصرف المعالجة إلا

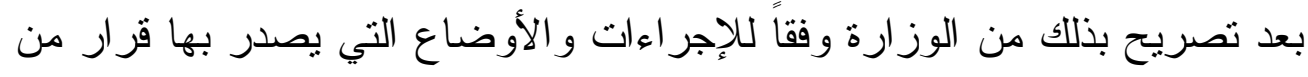

r-الإلز ام بعد بعدم إغراق المخلفات إلا بتصريح :

قام القانون بعمل إلزام يتمثل في عدم إغراق المخلفات أو أية مواد أخري

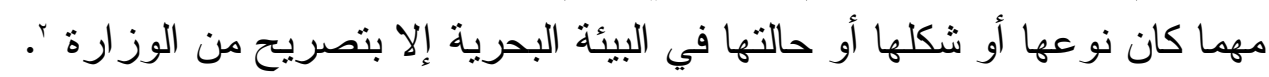
r- الإلز ام بالإبلاغ أي تسرب نفطي أو أي من ملوثات البيئة :

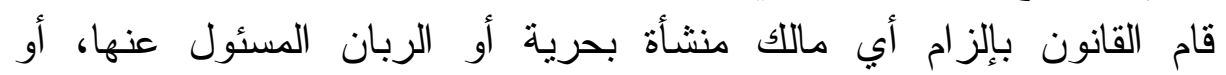

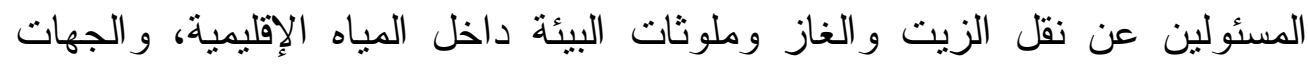

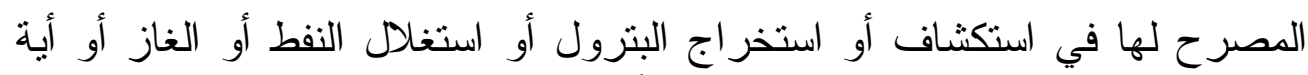

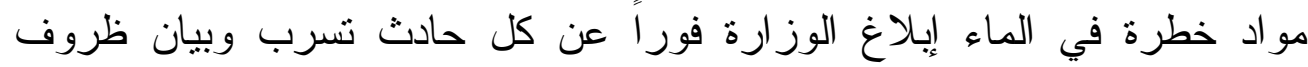

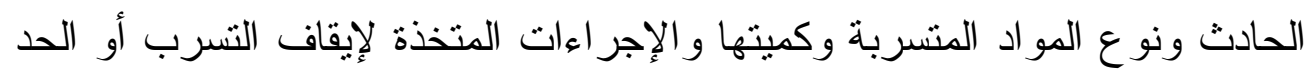
منه rان

ع -إلز ام الجهات بعدم إلقاء المخلفات إلا في الأماكن التي تحددها الوزارة :

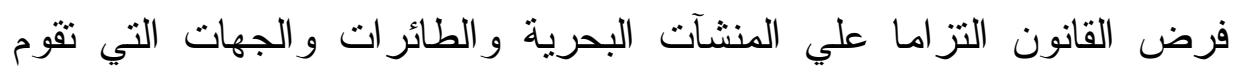
بأعمال استكثاف واستغلال الموارد الطبيعية أو أية أعمال أخري إلقاء المخلفات التهات أئاً

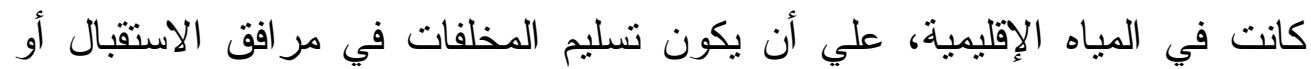

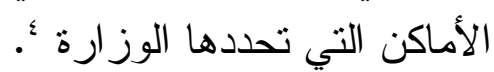

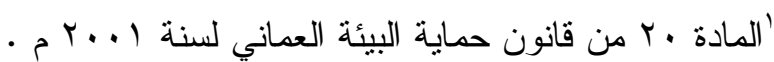

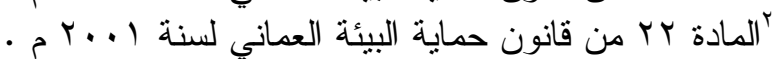

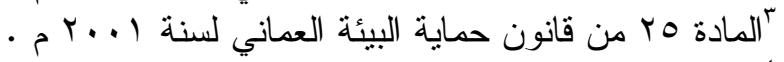

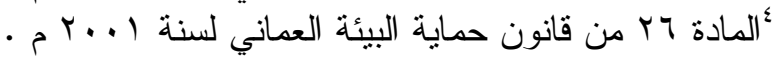




\section{ثالثاً - نشر المعرفة والتثقيف والوعي البيئي :}

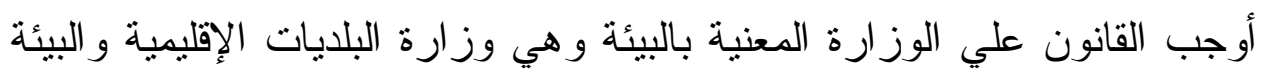

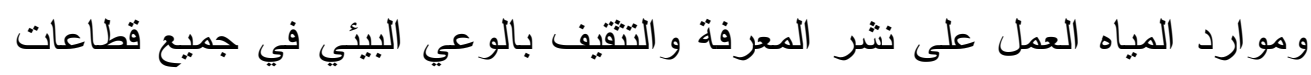

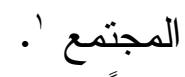

$$
\text { رابعاً - الحصول علي تصريح : }
$$

في إطار تحقيق نظام بيئي عام، أشترط المشرع لأجل حماية البيئة ضرورة

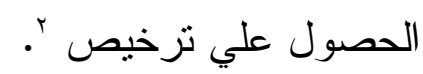
إذ أن هذا الوعي البيئي من شأنه أن يؤدي إلي إدرالي المو الطنين بضرورة

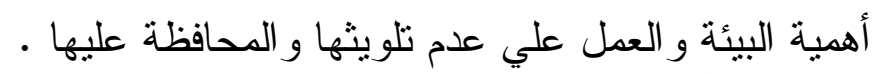

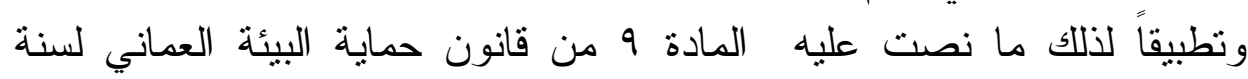

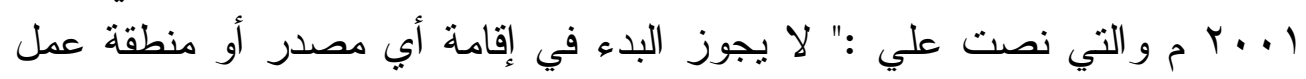

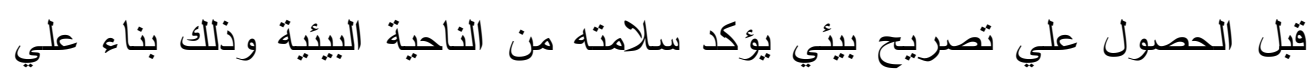

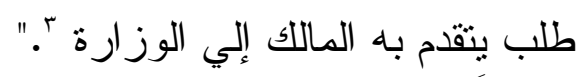

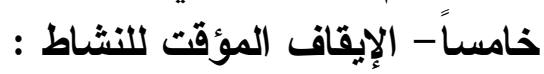

كل من يقوم بعمل قبل الحصول علي تصريح بيئي يؤكد سلامته من الناحية

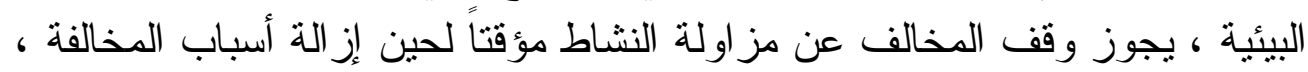

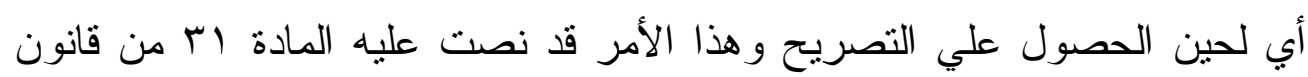

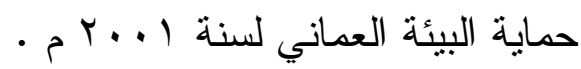

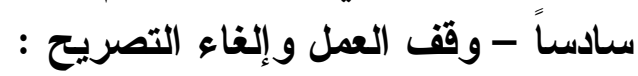

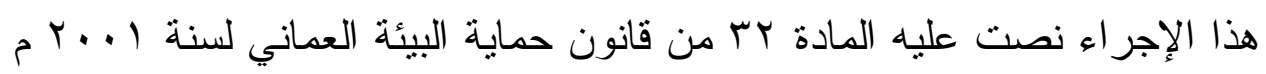

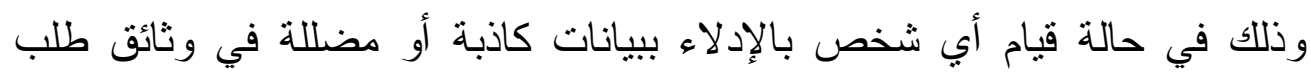
التصريح البيئي أو طلب الحصول علي موامقافي الفصل الوزارة علي إقامة مصدر أو منطقة عمل

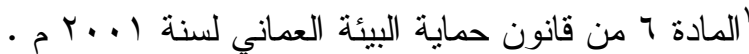

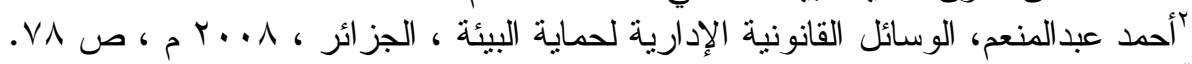

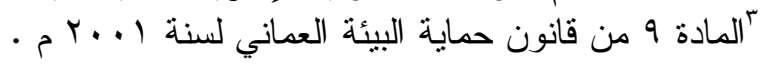




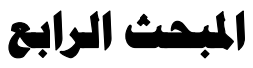

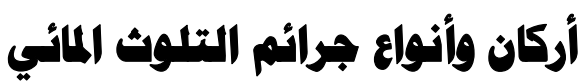

أولاًا-أركان جرائم التلوث المائي : أنوان

يتمتل الجزاء الدقرر للجريمة المتعلقة بالتلوث المائي في توقيع العقوبة علي

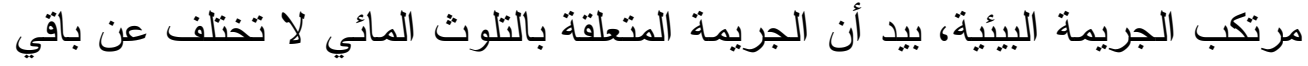

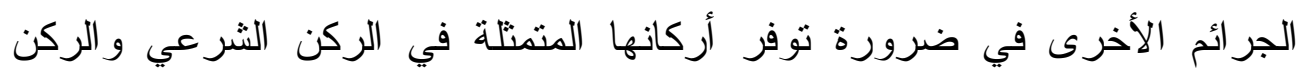

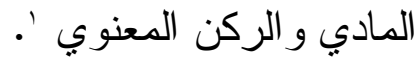

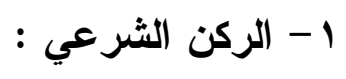

الدقصود بذلك أن يكون الفعل الذي نم ارتكابه جريمة في نظر القانون، إذ أنه

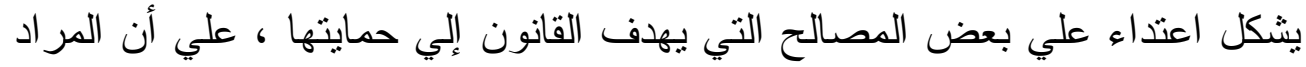

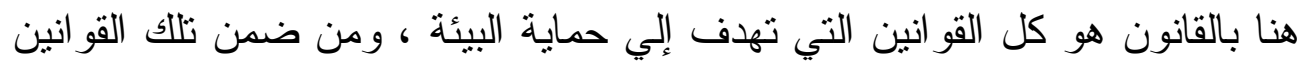

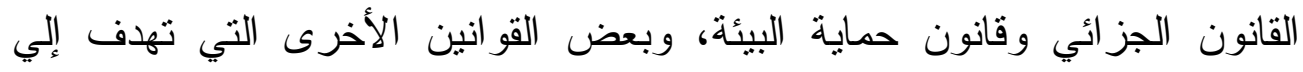

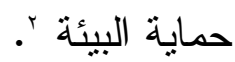

علي أن السبب في ذلك يعود إلى أن القانون البيئي قانون غائي وهذه الخاصية

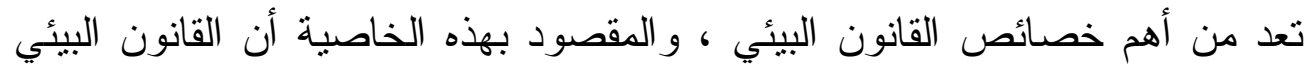

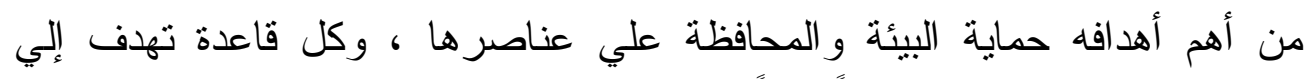

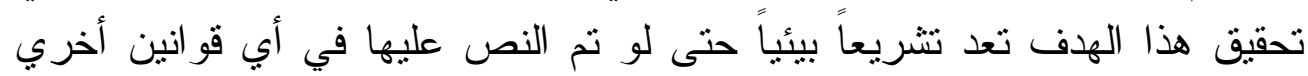

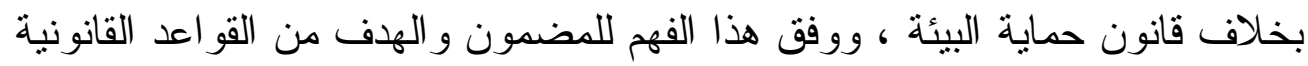

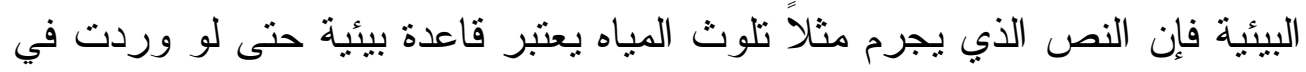

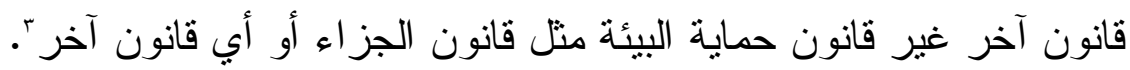

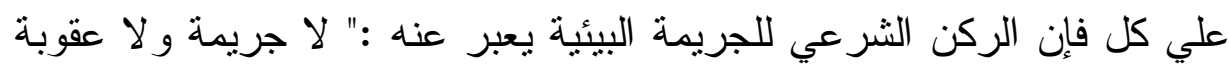

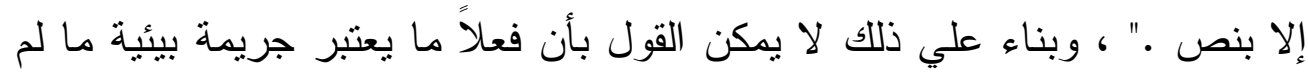

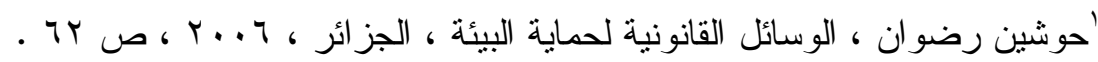

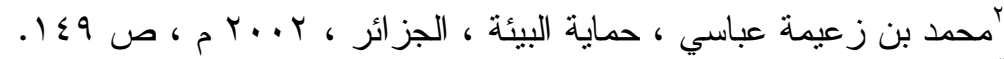

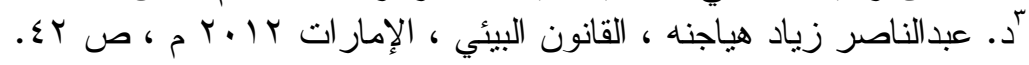


يكن هنالك نص علي تجريمه قبل وقوعه'، وبما أن موضوع در استتا حماية البيئة

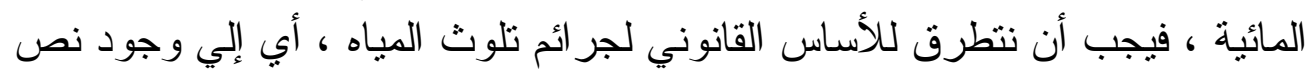

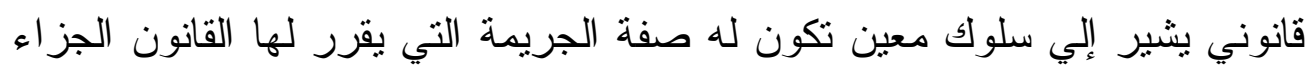

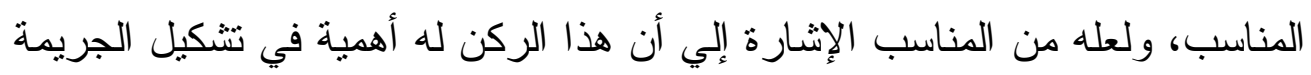

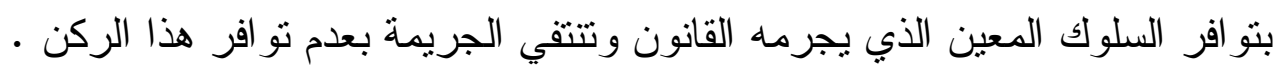

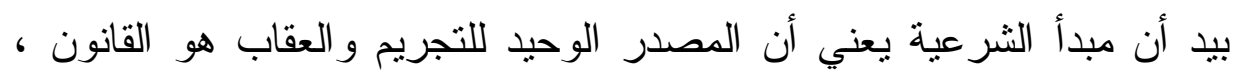

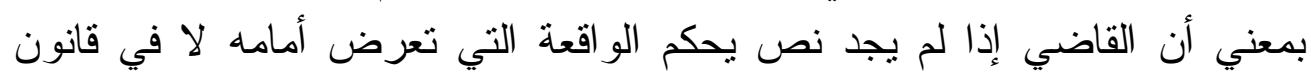

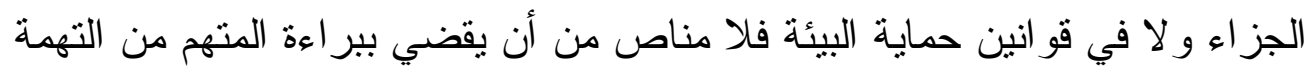

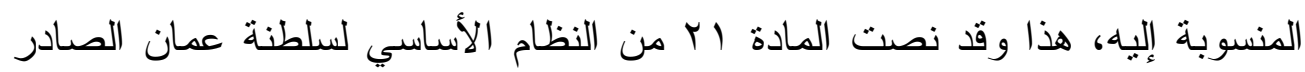

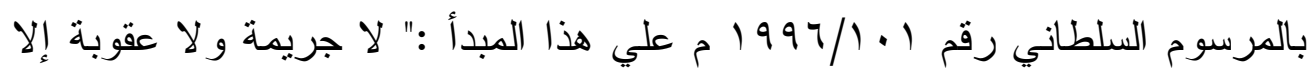

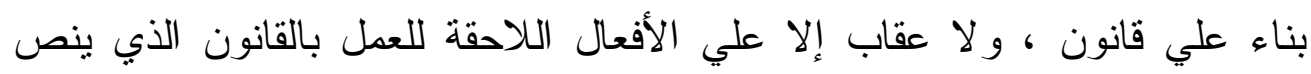

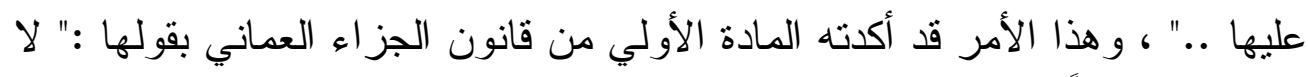

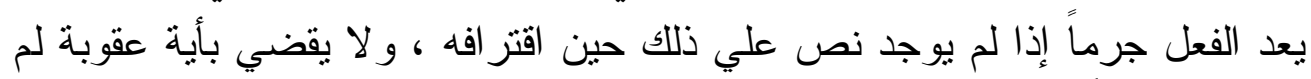

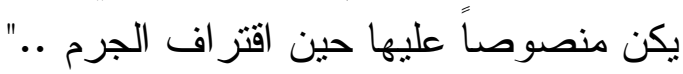

$$
\begin{aligned}
& \text { r - الركن المادي منومن }
\end{aligned}
$$

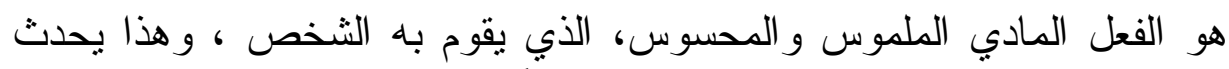

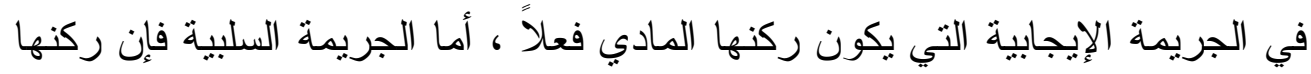

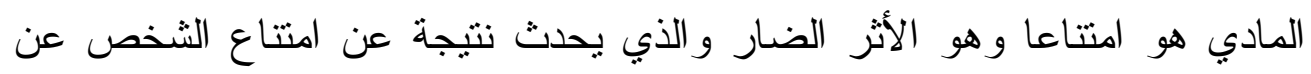

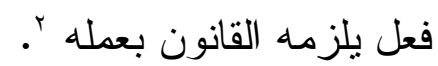

هذا ويتكون الركن المادي لجر ائم البيئة المائية من عدد من العناصر هي :

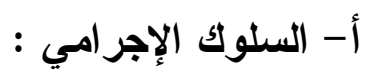
أ-1 - السلوك الإجر امي الإيجابي :

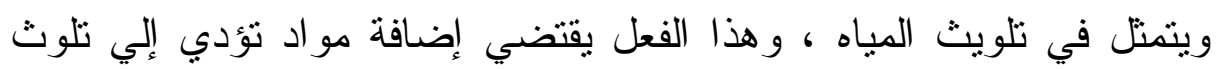

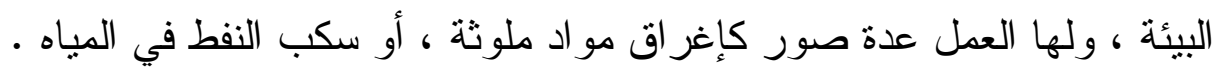
أ-r - السلوك الإجر امي السلبي :

'بوغالم يوسف ، المساعلة عن الجرائم البيئية ، مركز الدراسات العربية ، مصر ، 10 •ب م ص r

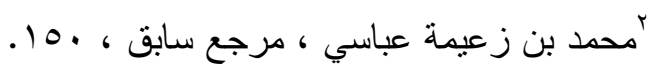


يتمنل ذلك في امتتاع الثخص عن تتفيذ بعض الالنزامات التي فرضها عليه

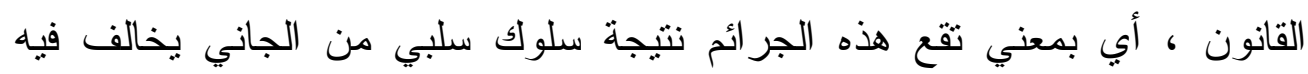

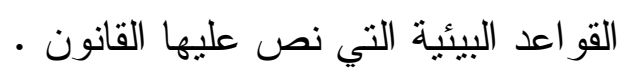

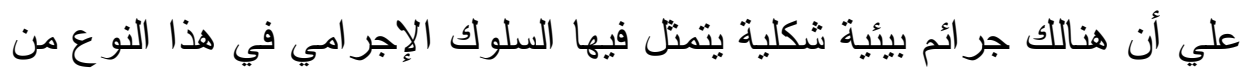

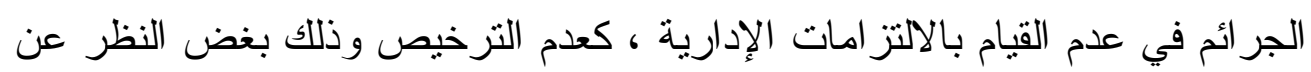

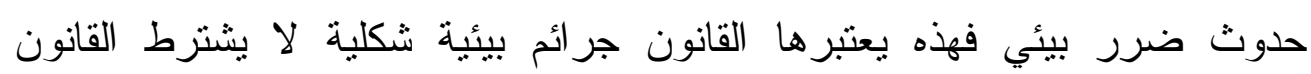

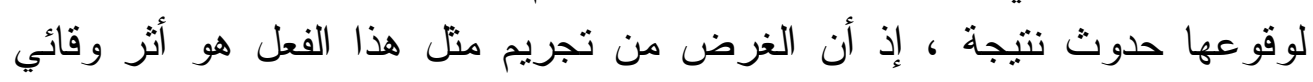

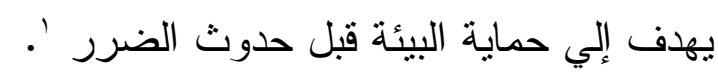

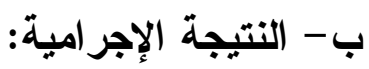

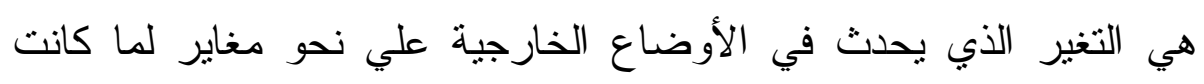

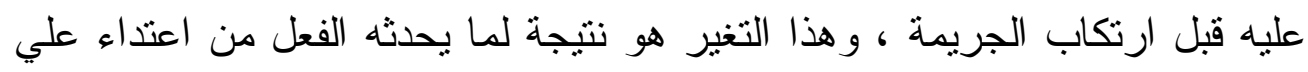

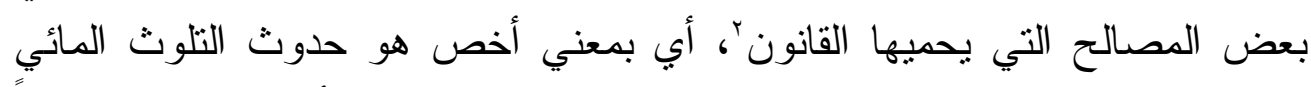

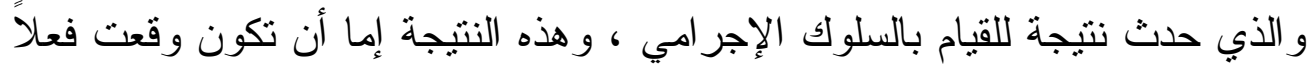

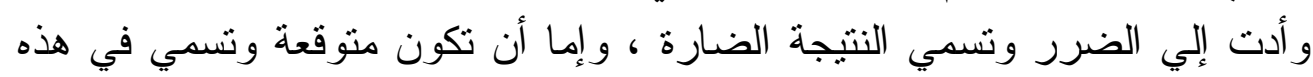

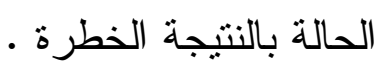

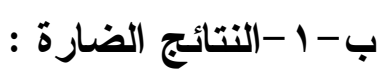

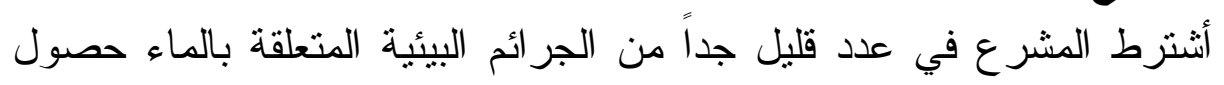

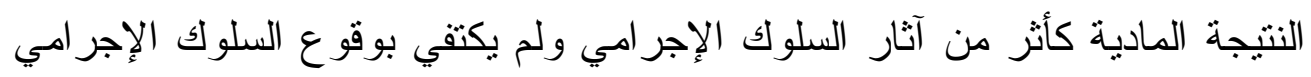

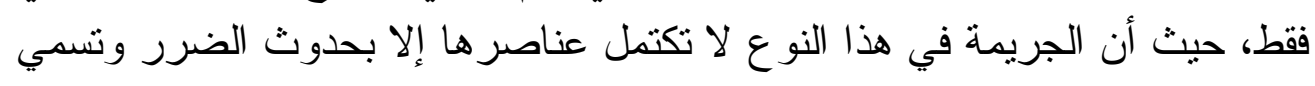

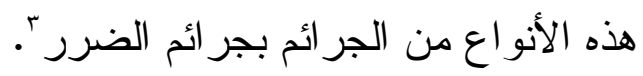

$$
\begin{aligned}
& \text { ب-r - النتائج الخطرة : }
\end{aligned}
$$

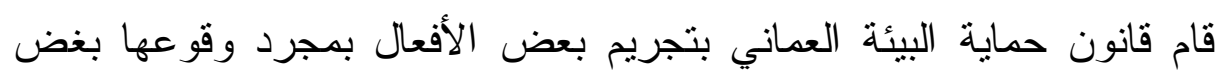

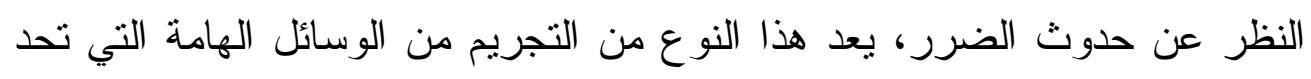

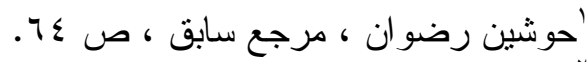

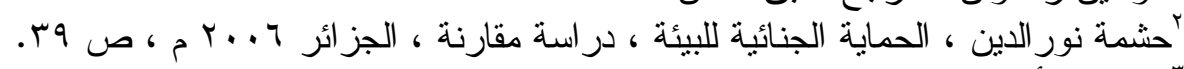

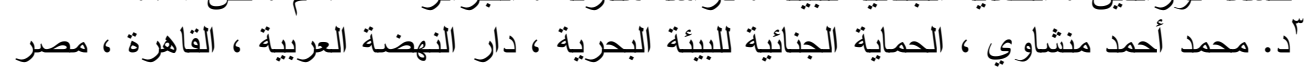

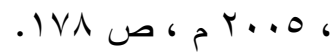


من الأضر ار التي قد يستحيل معها إرجاع البيئة لما كانت عليه قبل وقوع الضرر،

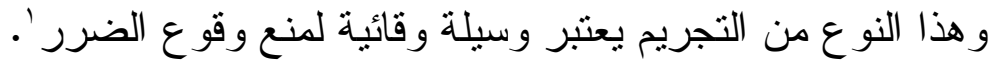

ج- علاقة السبيبة:

يعتبر السلوك الإجرامي في الجرائم التي تقع علي البيئة المائية وقيام النتيجة

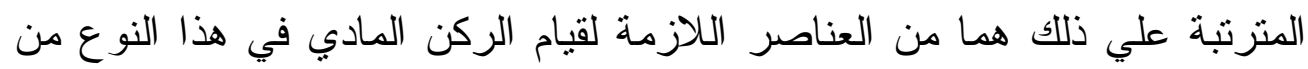
الجر ائم بجانب نو افر علاقة السببية و الي تربط بين الفعل بالنتيجة ، أي أن النتيجة التي حدثت كانت نتيجة منطقية لذلك السلوك الإجر امي.

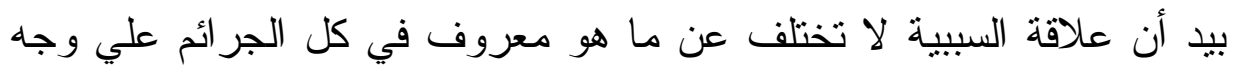

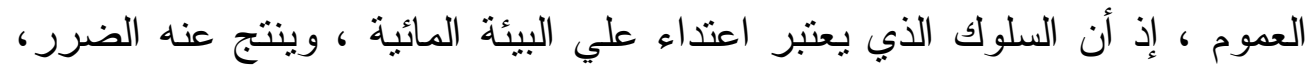

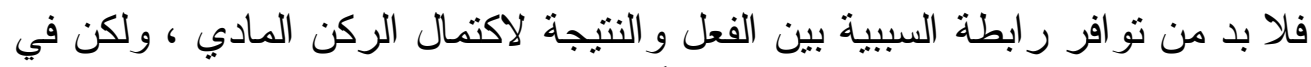

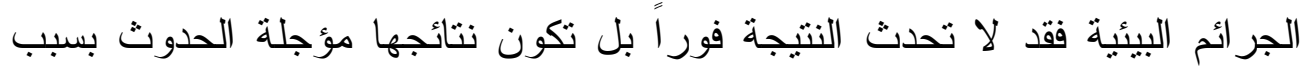
طبيعتها ، ففي هذه الحالة يكون الوصول لعلاقة السببية بالافتز اض الذي يقبله

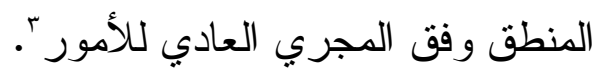

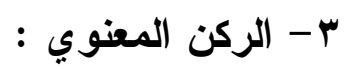

يتمنل هذا الركن في إر ادة الجاني التي يقترن بها السلوك الإجر امي ، أي نية

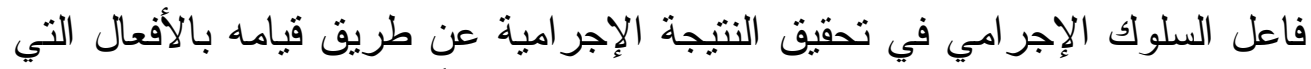

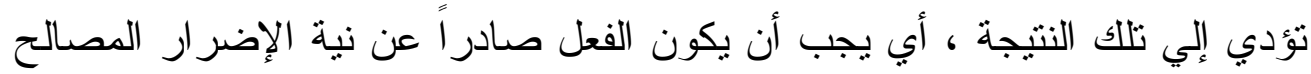

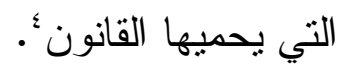
علي الرغم من أن الركن المعنوي يعتبر من أهم أركان أي جريمة، إلا أن

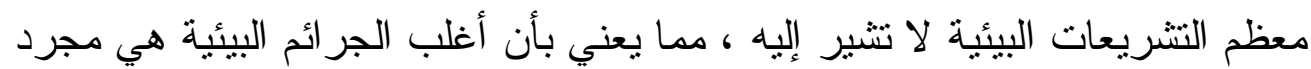
جر ائم مادية يستخلص الركن المعنوي المؤدي لها من السلوك الإجر امي فقطان.

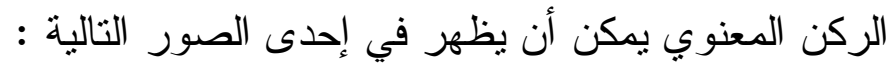

'د. نور الدين هنداوي ، الحماية الجنائية للبيئة ، دار النهضة العربية ، القاهرة ، مصر ، 1... م م ، ص س 9.

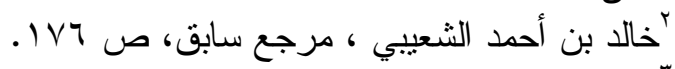

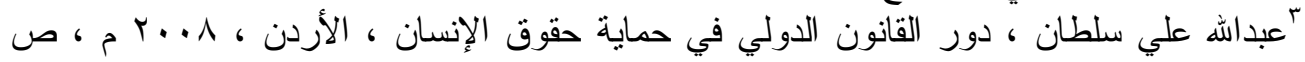
.9.

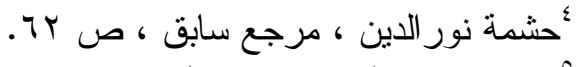

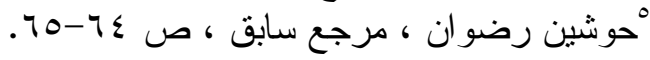


أ-القصد الجنائي :

يطلق عليه القصد الجنائي أو النية الإجر امية ، علي أن ذلك يتطلب تو افر العلم بالجريمة والحق المعتدي عليه ، مع احتمال أن يتسبب الفعل في جريمة متعلقة

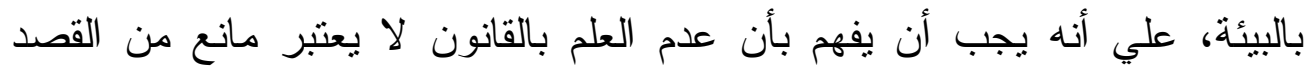

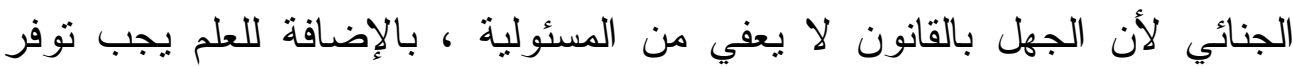

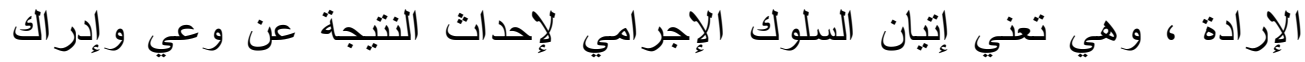

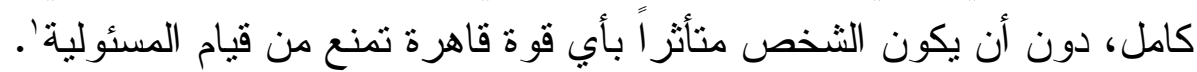

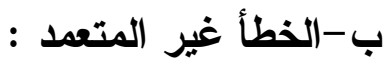
يأخذ هذا الخطأ صورة عدم أخذ الحيطة والحذر اللازمين ، أو عدم الانتباه ،

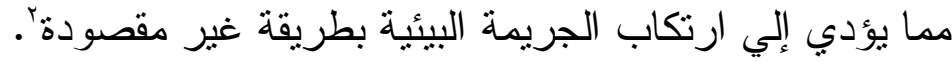

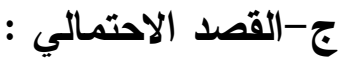

هنالك اتجاه أخذته بعض القوانين ومنها المشرع العماني باعتبار القصد الاحتمالي كأحد صور القصد الجنائي في بعض الجرائم المتعلقة بالبيئة، من منطلق

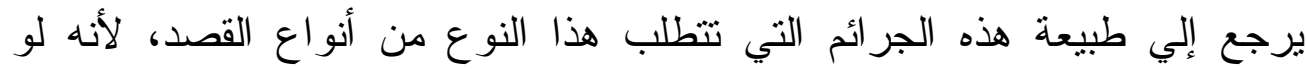

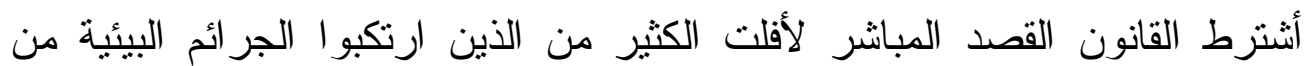

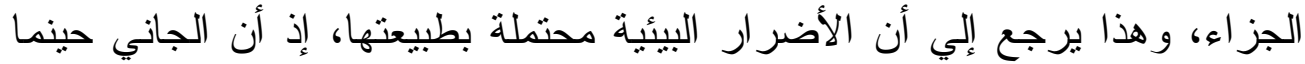

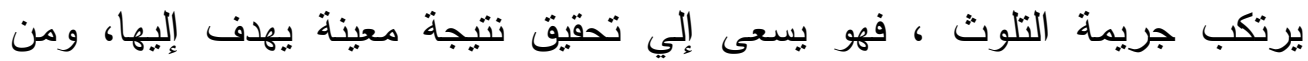

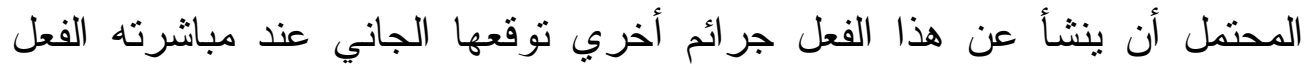

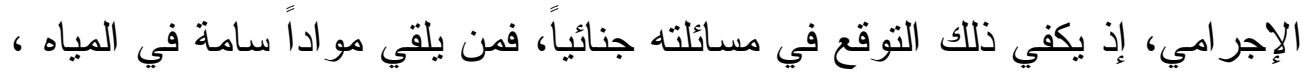

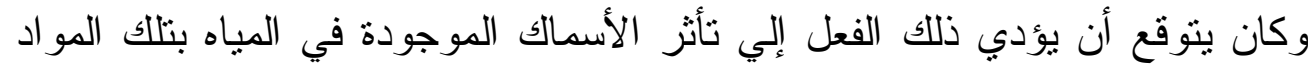

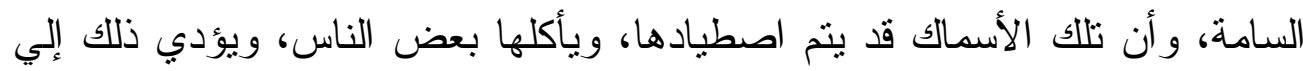

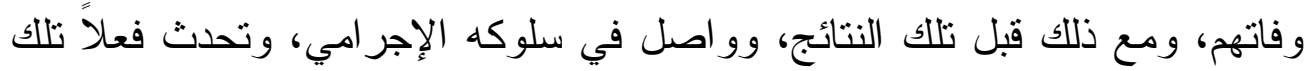

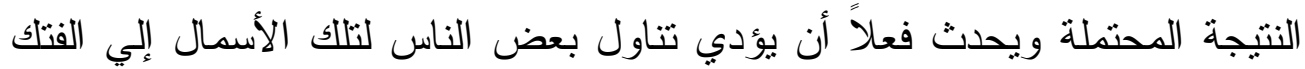

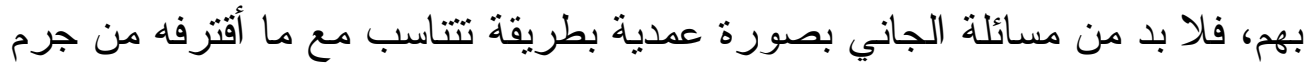

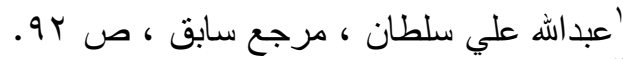

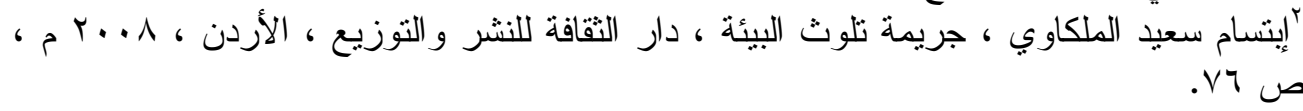


وضرر نوقعه ، ولم يثته ذلك التوقع عن الإقدام علي ذلك الفعل الذي يعتبر جريمة

$$
\text { بيئية يجب أن يعاقب مرتكبها' }
$$

ثانياً - جر ائم تلويث البيئة المائية :

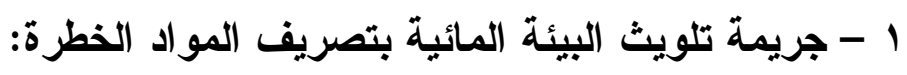

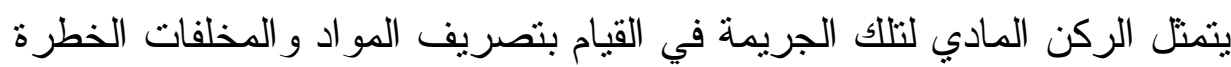
و غيرها من ملوثات البيئة في الأودية أو مجاري المياه أو مناطق لتئية تغذية المياه

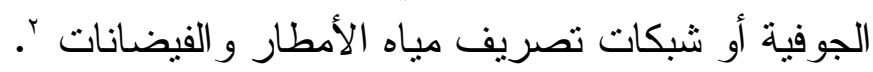

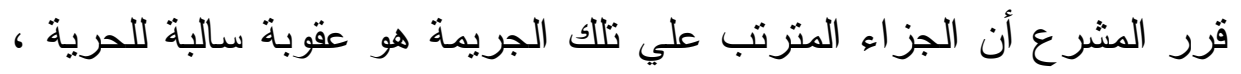

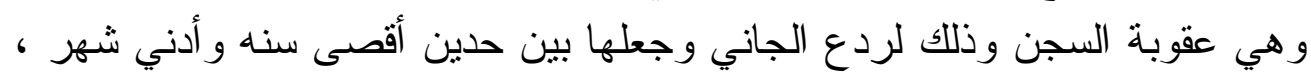

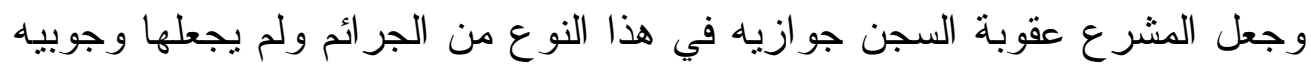

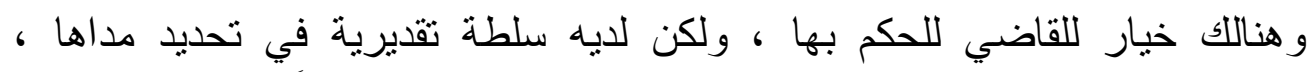

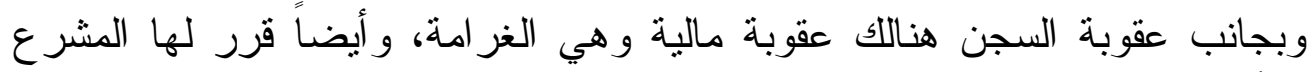

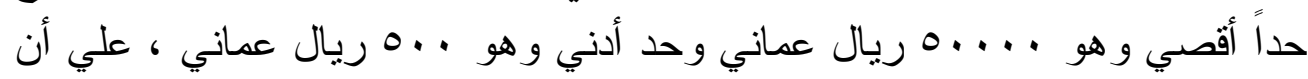
للقاضي الخيار في أن يحكم بعقوبة السجن بجانب الغرامة أو إحدي هاتين وهين

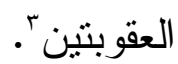

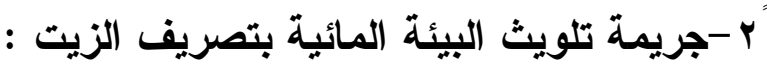

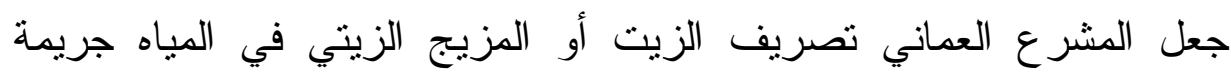

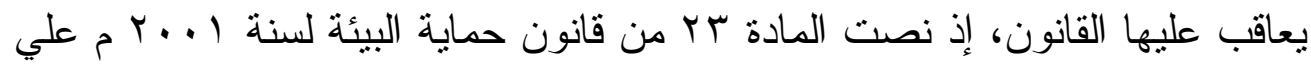
أنه :" يحظر علي جميع السفن تصريف الزيت أو المزيج الزيتي أو أي ملوثات بيئية

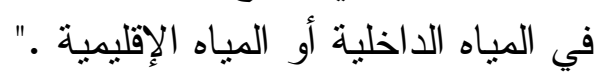

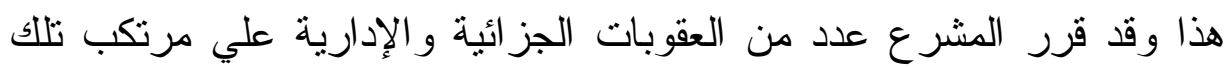

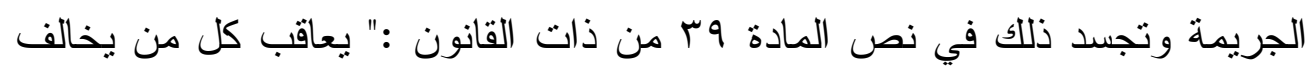

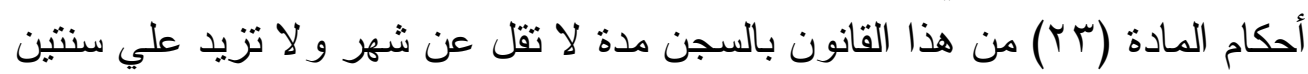

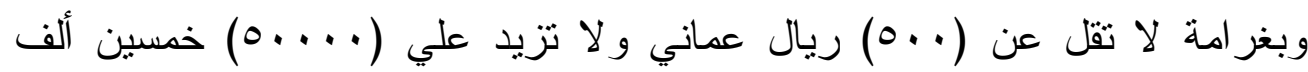

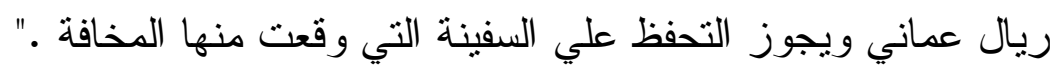

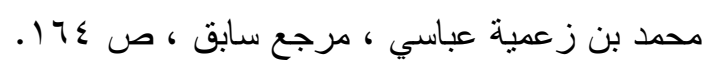

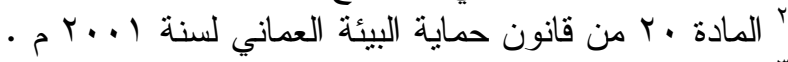

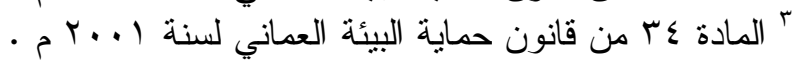




\section{ب-جريمة التخلص من المخلفات النووية :}

جرم المشرع العماني هذا الفعل الذي بعتبر ضار اً بالبيئة ضرراً كبيراً، لأن

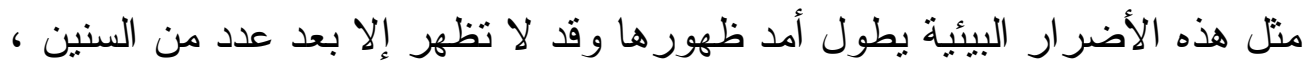
كما تتميز هذه الجرائم بعموم ضررها وشموليته ، فهي في حالة وقوعها تضر بكائنات عديدة كالحيو انات التي تعيش في المياه و النباتات التي تكون علي الثو اطئ و التي يصيبها التلف من الماء الملوث ، ويمس هذا الضرر قطاعاً كبير ا'. نظر اً لخطورة هذه الجريمة قرر لها المشر ع العماني أقصي أنواع العقوبات

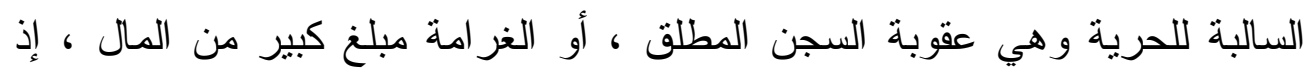

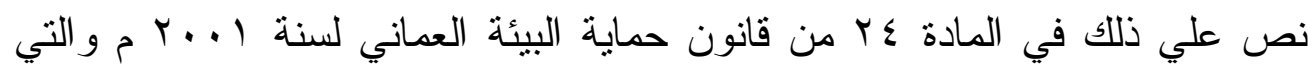
نصت علي :" مع عدم الإخلال بعقوبة أثند ينص عليها قانون آخر يعاقب كل من يقوم بالتخلص من المخلفات النووية في البيئة العمانية بالسجن المطلق (المؤبد)

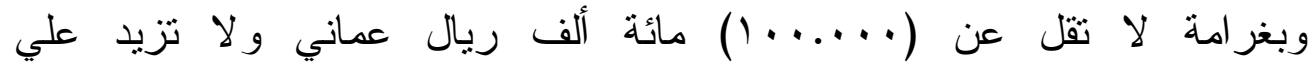

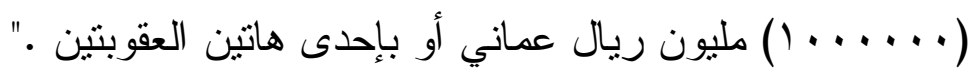
ع - تجريم وقائي الهرف منه الحد من تلوث البيئة المائية : أ-جريمة عدم تثفيذ التعليماث وعدم الاحتفاظ بالسجلاث : يتمثل النشاط الإجر امي في عدم قيام ربان السفينة بالاحتفاظ بسجل يدون فيه جميع

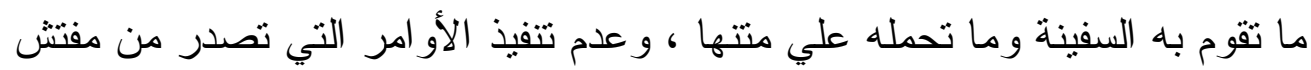
البيئة ، وبما أن هذه الجريمة الهدف منها وقائي فقد جعل المشرع العماني عقوبتها خفيفة تتمنل في الغرامة فقط بمبلغ وقدره ( . . . 1) ألف ريال عماني ولا تزيد عن ( . (0) خمسة ألف ريال عماني ، ولكن الغرامة يمكن أن تتضاعف بتكرار

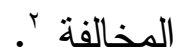

\section{ب- جريمة عدم الإبلاغ عن حادث تسرب الزيت :} جعل المشرع العماني عدم الإبلاغ عن حادث تسرب الزيت فور وقوعه إلي الجهات الإدارية جريمة ويعاقب مرتكب هذه الجريمة بالغرامة ( . . . 1) ألف ريال عماني ولا تزيد عن ( . ..0) خمسة ألف ريال عماني ، ويمكن أن تتضاعف هذه

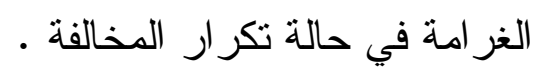

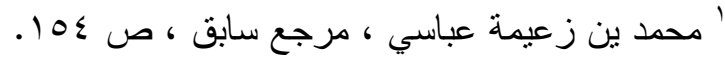

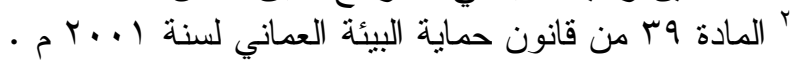


وتجسد هذا الأمر في نص المادة مب من قانون حماية البيئة لسنة ا . . r م إذ نصت علي :" علي مالك أية منشأة بحرية و الربان و المسئول عنها ، و المسئولين عن هن نقل الزيت و الغاز وملوثات البيئة داخل المياه الإقليمية ، و الجهات المصر ح لها في استكثاف أو استخر اج أو استغلال النفط و الغاز أو أية مواد خطرة في الماء إبلاغ الوزارة فوراً عن كل حادث تسرب وبيان ظروف الحادث ونوع المادة المتسربة وكميتها و الإجر اءات المتخذة لإيقاف التسرب أو الحد منه ." فئرن

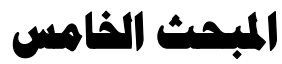

\section{المسئولية والتمعويض مغ تلويث البينة المائية والماكم المفتصة}

أولاً: المسئولية المدنية و التعويض :

إن المسئولية المدنية عن الأضرار تقوم علي مبدأ الملوث بدفع أو (مسؤولية الملوث) ، إذ أن هذا المبدأ يقوم علي مسؤولية محدث التلوث عن تعويض كل الأضرار التي تسبب فيها، كما أن عليه تحمل الجزاءات الجنائية التي قررها القانون بشأن الجرائم البيئية و المخالفات ، إذ لا بد أن يتحمل محدث الضرر تبعات تصرفه ، بحيث يتحمل التعويض عن الضرر وضرورة إصلاحه، إذ أن هذا المبدأ يسعي لتحقيق هدف رئيس هو إلز ام ملوث البيئة بدفع التكاليف و التعويض المناسب وذلك لمعالجة التلوث الذي أحدثه وذلك ردعاً له حتى لا يكرر هذا الفعل مرة أخري وردعاً لغيره حتى لا يقدم علي هذا الفعل لأنه يعلم بأنه سيترتب عليه ما ترتب علي من سبقه في الإتيان بهذا السلوك المجرم بيئياً. علي كل فإن الكثير من التشريعات الوطنية للعديد من دول العالم تركت أمر المسئولية والتعويض عن الأضرار تحدث عن تلوث المياه محكومة بالقو اعد العامة للمسئولية المدنية عن الفعل الضار رغم الخصائص التي تتميز بها الأضر ار البيئية. إلا أن المشرع العماني أحسن صنعاً عندما أورد الأحكام الخاصة و المتعلقة بالتعويض في قانون حماية البيئة.

هذا وقد قام المشرع العماني بتحديد المسئولية المترنبة علي الأضرار التي تحدث نتيجة للتلوث المائي في عدة صور منها :

' د.عبدالناصر زياد هياجنة ، مرجع سابق ، ص ع ج. 
قرر المشرع التعويض كأحد الجز اءات المقررة لجر ائم تلويث المياه، وذللك بدفع المان

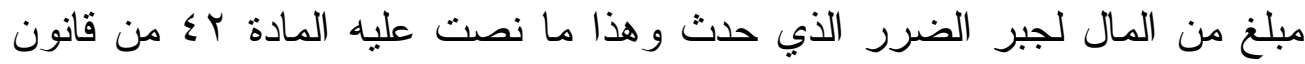

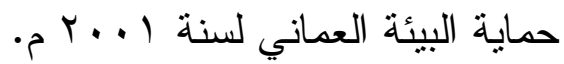
علي أن التعويض عن الأضرار البيئية يشمل التعويض عن التئن الأضرار تلحق

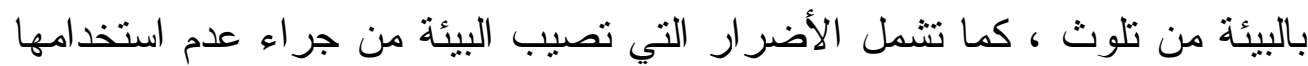

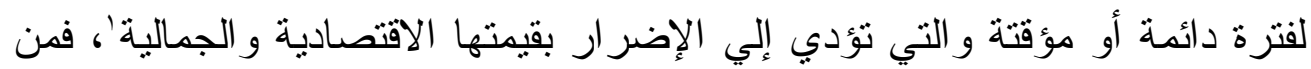
يصيب بالبيئة المائية بالتلوث النفطي أو النووي فئدي الإن ذلك من شأنه أن يؤدي إلى في عدم

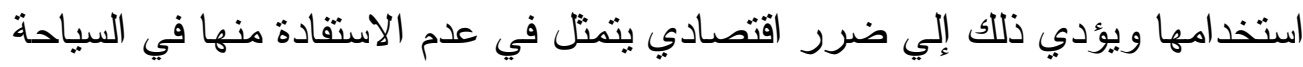

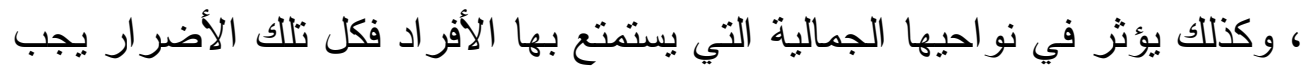

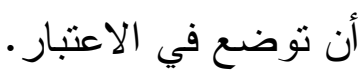

\section{r-إعادة الحال إلي ما كان عليه :}

يعني ذلك أن يلتزم مرتكب الفعل الضار بإعادة البيئة إلي الوضع الذاني الذي كانت عليه قبل وقوع الفعل الضار، فمن يقوم بالتخلص من المخلفات النووية في البيئة

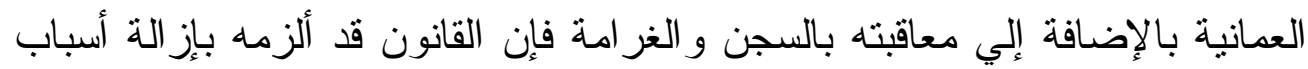

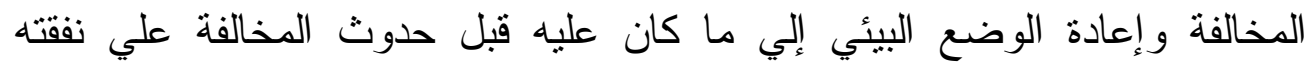

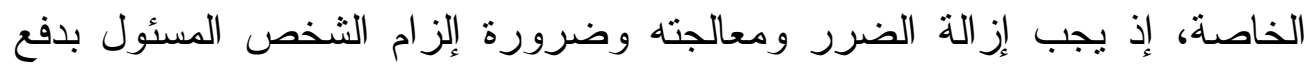

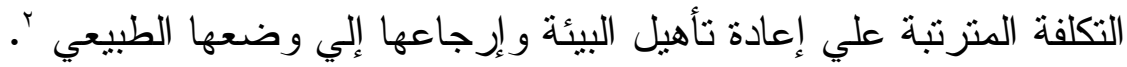

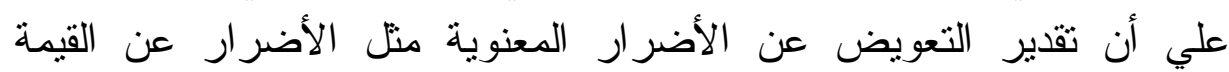

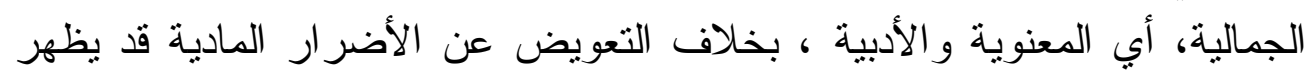

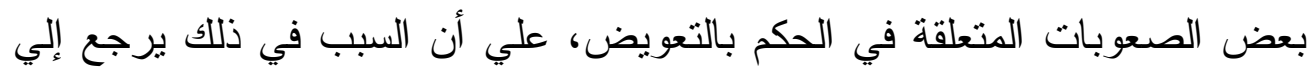

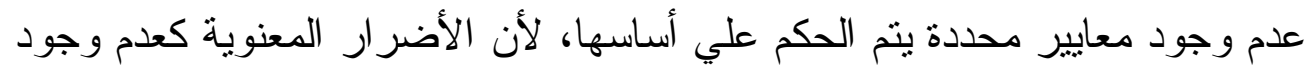

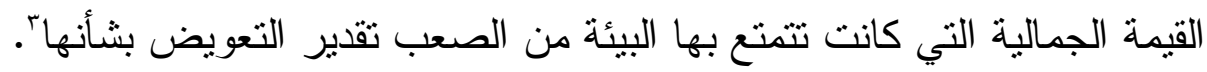

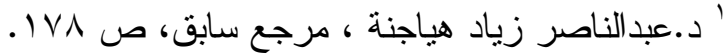

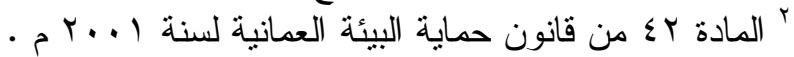

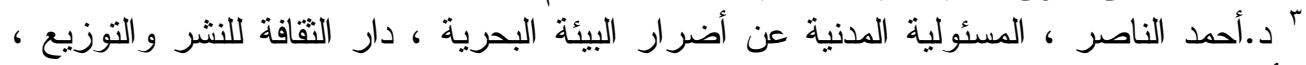

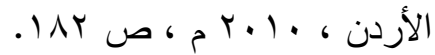


لبست هنالك محاكم خاصة بالبيئة، وبالتالي بنعقد المحاكم الجز ائية العمانية بنظر

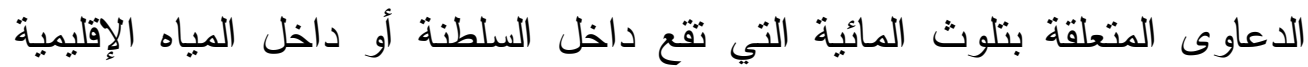

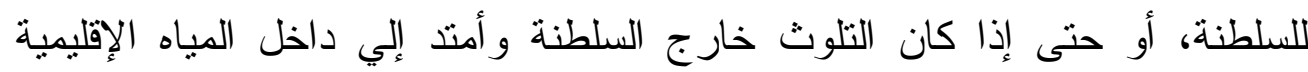

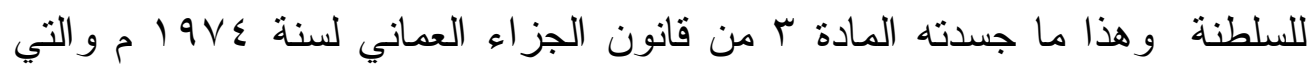

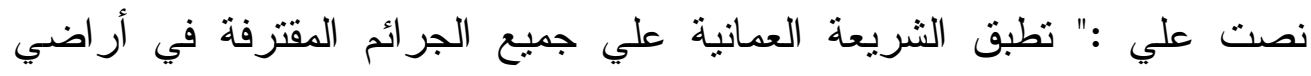

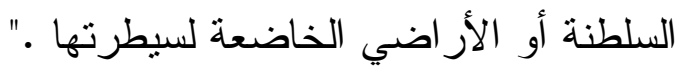

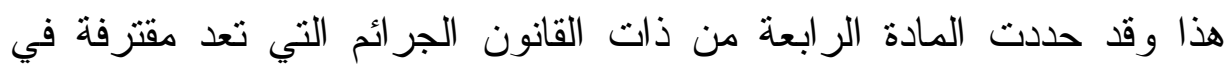

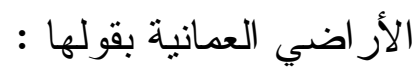

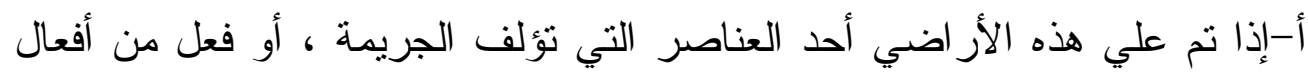

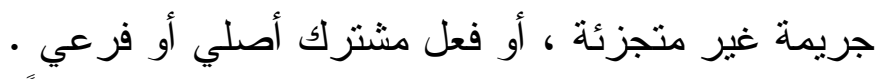

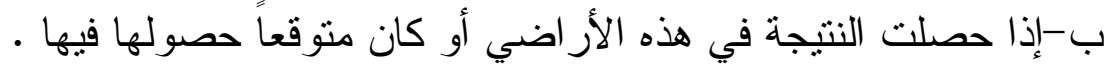

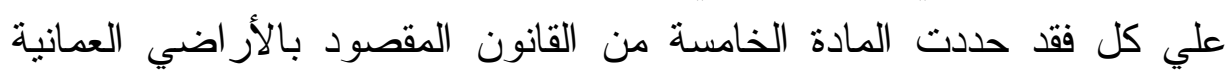

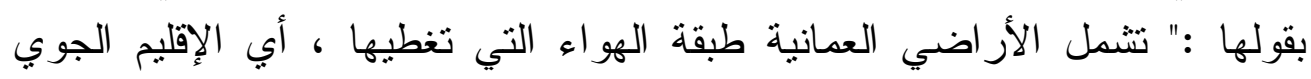

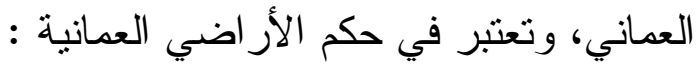

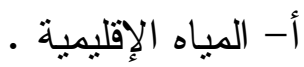

ب-المدى الجوي الذي يغطي المياه الإقليمية .

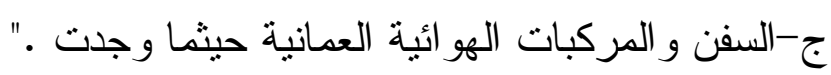

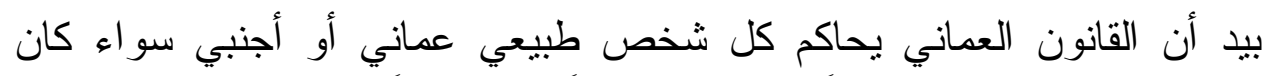

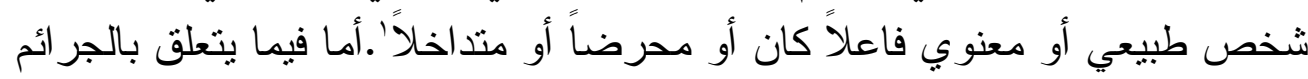

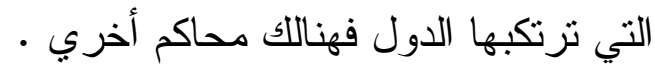
: r التحكيم

عادة ما تلجأ الدول إلي التحكيم ولدينا عدة تطبيقات في هذا الثأن سوف

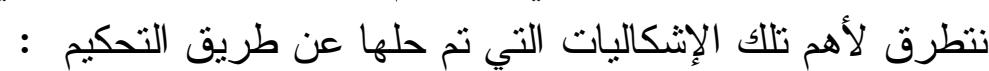

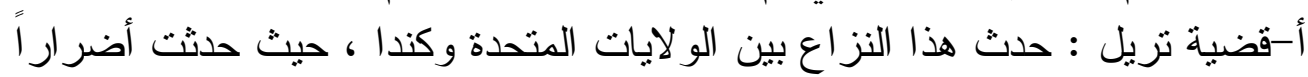

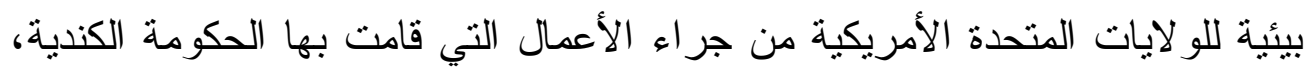

' المادة 1 من قانون الجزاء العماني لسنة ع ا9 19 م . 
بحيث إنتهت الحكومنين إلي إحالة النزاع إلي التحكيم ، هذا وقد قضت هيئة التحكيم

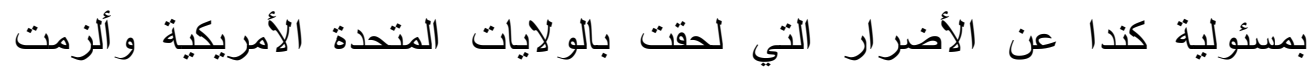

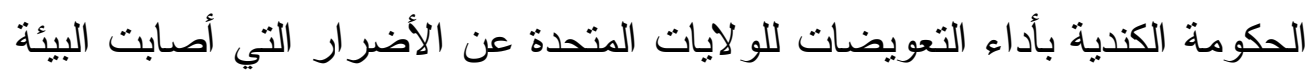

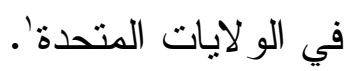

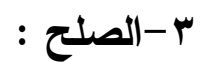

أدي اصطدام السفينة حادثة السفينة توري كانيون بالصخور إلي تسرب كميات

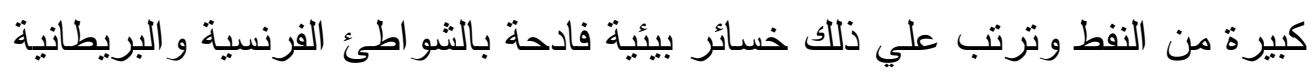

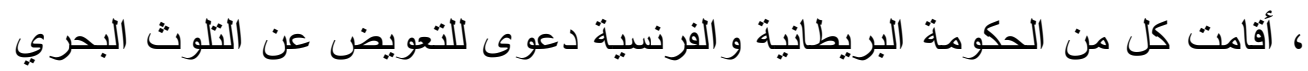

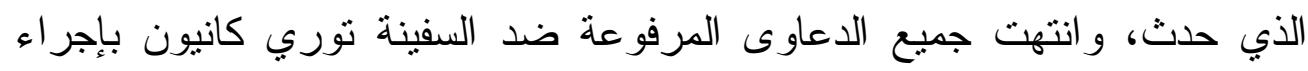

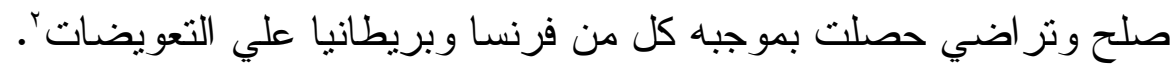

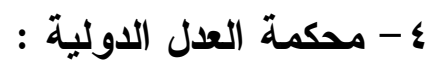

حدث ذلك في قضية الحكومة البريطانية ضد حكومة البهة ألبانيا في قضية مضيق

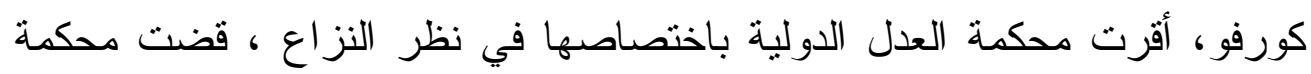

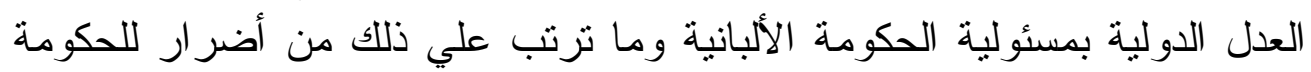

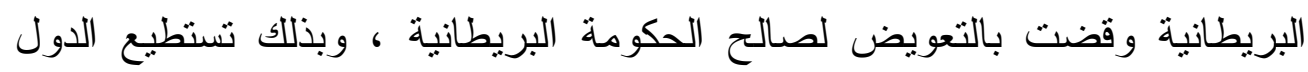

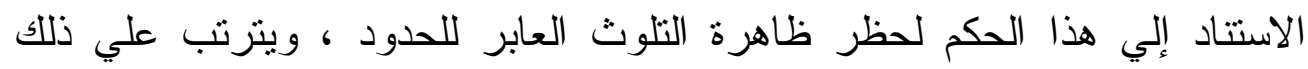

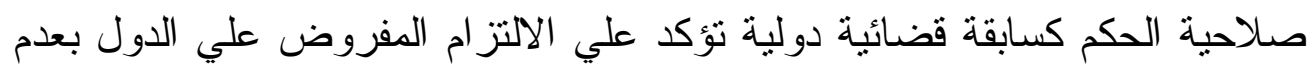

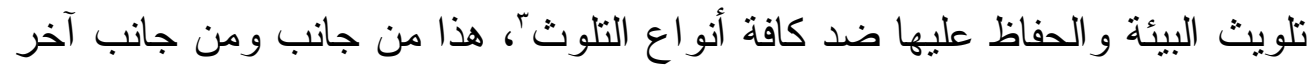

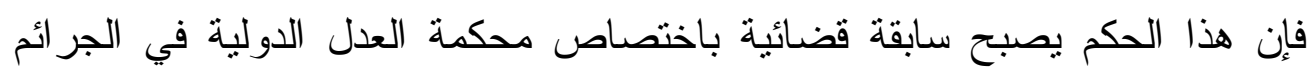
المتعلقة بالتلوث المائي ويمكن لكافة الدول في المجتمع الدولي الاستتاد لتلك السابقة

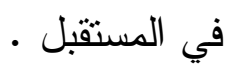

' د.صلاح هاشم ، المسئولية الدولية عن المساس بسلامة البيئة البحرية ، القاهرة ال199 م ، ص .

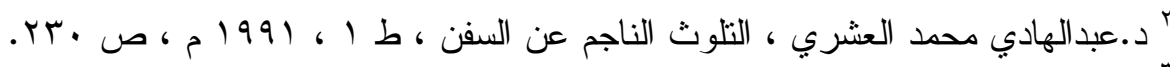

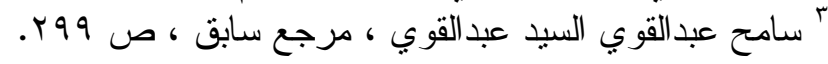




\section{الخاتمة}

نحمد اله تعالي الذي أعانني علي إنجاز هذا البحث و أقول بأن الخاتمة نتنمل

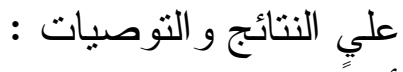

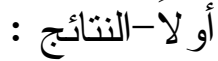

ا-ليس هناللك محاكم متخصصة لنظر القضايا المتعلقة بحماية البيئة بشكل عام وحماية البيئة المائية بشكل خاص وإن الإختصاص في هذا المجال ينعقد للمحاكم

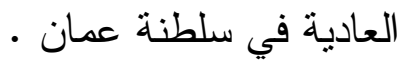
r-هناللك حاجة ماسة للوعي البيئي بشكل عام وللوعي بالبيئة المائية بشكل خاص وضرورة المحافظة عليها ـ ماجة ماعة r-ضرورة وجود الجهات ذات المعرفة البيئة المتخصصة و التي لها إدر الك بالقو انين و اللوائح بالإضافة للجو انب الفنية المتعلقة بالبيئة المائية .

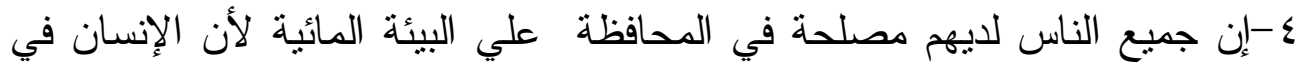
حاجة ماسة للمياه للشرب ولكافة الاستعمالات الأخرى.

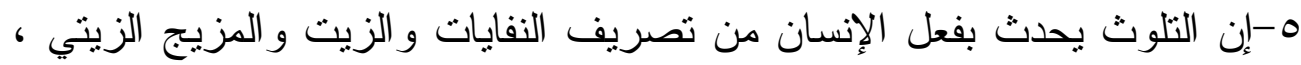

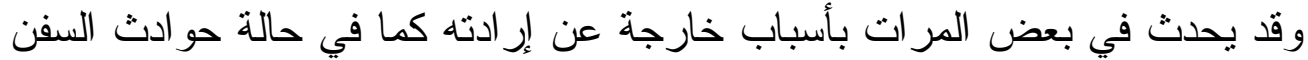

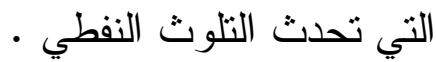
ه-هناللك العديد من الأسباب التي تؤدي إلي تلوث مياه البحار من ضمنها عمليات

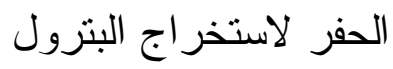

צ- من الأسباب التي تؤدي للتلوث تلف بعض الترو الخطوط الناقلة للبترول ويؤدي

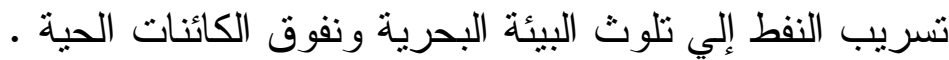
V- Vناللك الكثير من الحالات التي لا تتم فيها الإجر اءات بصورة سليمة ومر اعاة

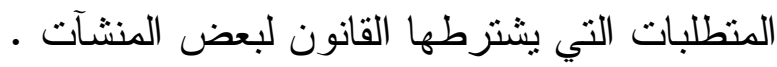
ᄉ-عدم وجود سو ابق قضائية في مجال البيئة المائية ، و هذا يؤكد إما عدم الوعي لاعي الوفي

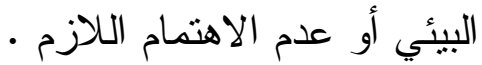
9- العمل علي تأهيل الإدارات التي تعمل في فلي مجال حماية البيئة المائية و إعطائها

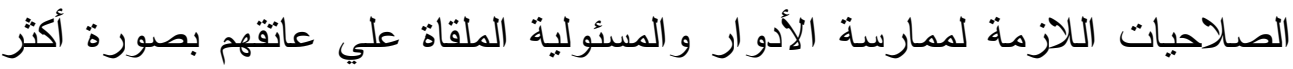

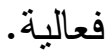
• ا-ليس هنالك عمل طوعي كافي للاهتمام بالبيئة المائية و المحافظة عليها، إذ أن أن النيأ هنالك غياب للجمعيات الطوعية التي تعني بحماية البيئة المائية . 
ا ا -هنالك قلة في الدر اسات القانونية المتعلقة بحماية البيئة المائية بشكل عام و البيئة المائية بشكل خاص في سلطنة عمان - النئ

التوصيات

ا-إنشاء محاكم مختصة تعني بقضايا البيئة بشكل عام وقضايا نلوث البيئة المائية بشكل خاص، بالإضافة إلي تأهيل قضاة متخصصين في مجال حماية البيئة يحملون المؤهلات الكافية التي تمكنهم من ردع كل من تسول له نفسه تلويث البيئة وتطبيق

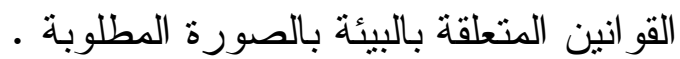

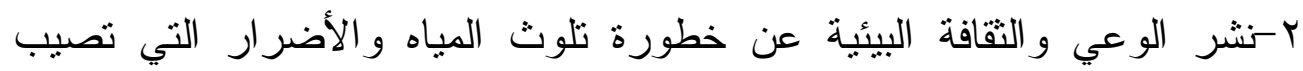
الإنسان بطريقة مباشرة وغير مباشرة وكذلك الأضر ار التي تصيب الكائنات الحية

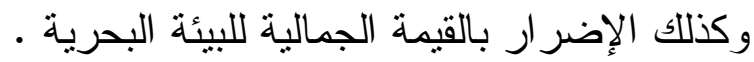
ب-عمل محاضر ات متخصصة وندوات وحلقات بحث وورش عمل ومؤتمر ات لنشر التوعية بالبيئة المائية وضرورة المحافظة عليها ضد كافة وأثكال صور التلوث ع بيجب علي الجميع بما فيه الحكومات و الأفراد العمل علي المحافظة علي البيئة المائبة. ه-إتخاذ الحيطة والحذر أثتاء عمليات الحفر لإستخر اج البتزول حتى لا يتسرب البترول للبيئة المائية . ج-صيانة أنابيب البترول بصورة دورية حتى لا يصيبها التلف ويتسرب منه البترول ويؤثز علي البيئة البحرية . V- ضرورة ممارسة الرقابة الإدارية من قبل الوزارة المختصة و التأكد من أن كل

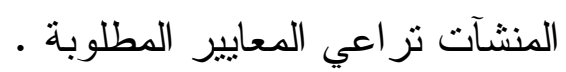
1-لا بد من الإبلاغ عن كل حو ادث التلوث وضرورة محاكمة مرتكبها حتي يكون ذلك عظة له حتى لا يقوم بتكر ار هذا الفعل مرة أخري و عظة كذللك لغيره إذ يكون

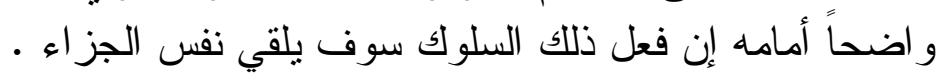
9-لا بد للإدار ات التي تعمل في مجال حماية البيئة من أن تكون بالقوة و الصر امة التي تمكنها من أداء دور ها في المحافظة علي البيئة البحرية. • ا-تشجيع العمل الطوعي في مجال حماية البيئة المائية و العمل علي قيام جمعيات طو عية تعمل في مجال حماية البيئة البحرية . مئية ا ا تشجيع البحث العلمي في مجال حماية البيئة بصورة عامة وحماية البيئة المائية بشكل خاص من قبل الجامعات ومر اكز البحث العلمي . 
